\title{
Precambrian tectonic inheritance control of the NE Brazilian continental margin revealed by Curie point depth estimation
}

\author{
Jefferson Tavares Cruz Oliveira*,1, José Antonio Barbosa ${ }^{1}$, David Lopes de Castro², \\ Paulo de Barros Correia ${ }^{1}$, José Ricardo Gonçalves Magalhães ${ }^{3}$, \\ Osvaldo José Correia Filho ${ }^{1}$ and Bruno Varela Buarque ${ }^{1}$ \\ (1) Federal University of Pernambuco, Geoquantt Research in Geosciences, Department of Geology, Avenida Acadêmico \\ Hélio Ramos, s/n, Cidade Universitária, Recife - PE, Brazil, 50740.530 \\ (2) Federal University of Rio Grande do Norte, Department of Geology, Campus Universitário s/n, Lagoa Nova, Natal - RN, \\ Brazil, 59072-970 \\ (3) Federal University of Recôncavo, Exact and Technology Sciences Center, Campus, Cruz das Almas - BA, Brazil, 44380-000
}

Article history: received January 30, 2020; accepted December 7, 2020

\begin{abstract}
An investigation of Curie point depths (CPD) based on spectral analysis of airborne magnetic data was carried out in the NE Brazilian continental margin. The studied region represents a narrow hyper-extended margin with three sedimentary basins. Regional geothermal gradient and heat flow were also calculated. CPD results were integrated with interpretation of 2D deep seismic data and with estimated isostatic Moho depths. The results reveal that the narrow hyper-extended crust is $150 \mathrm{~km}$ wide in the southern sector and $80 \mathrm{~km}$ wide in the north, with a narrow ocean-continental transition (OCT) zone that varies from $50 \mathrm{~km}$ wide in the south sector to 30 to $20 \mathrm{~km}$ wide in the north. The CPD isotherm showed the strong influence of the three main continental blocks of Borborema's Shield in the tectonic evolution of the three marginal basins. The CPD analysis corroborated models provided by gravimetric data and successfully demonstrated the sharp control of basement compartments on the thermal properties of the marginal basins domains.
\end{abstract}

Keywords: Curie Point Depth; Rift margin evolution, basement inheritance; Transitional crust; Borborema Province.

\section{Introduction}

Magma-poor hyper-extended margins are characterized by a hyper-thinned zone of continental crust, which involves deep faulting within the crust and formation of mantle-rooted detachment zones [Reston, 2009; PérezGussinyé, 2013; Sibuet and Tucholke, 2013; Franke, 2013; Guillot et al., 2015; Gillard et al., 2017]. Those margins show little syn-rift magmatism and a continent-ocean transition formed by mantle exhumation, leading to serpentinization, which preceded the oceanic spreading. Two characteristics are most distinctive [Reston, 2009]: 


\section{Jefferson Tavares Cruz Oliveira et al.}

1 - extreme crustal thinning - hyper-extended crust ( $\sim 30 \mathrm{~km}$ to a few kilometers over a distance of 100-200 km), 2 - a sector of anomalous basement, between the last identifiable continental crust and the true oceanic crust. This zone of "intermediate" crust is formed by the process of mantle exhumation with a variable degree of serpentinization, which is named ocean-continent transition zone (OCT).

The eastern continental margin of northeast Brazil represents part of the central segment of the South Atlantic Ocean (Figure 1). This region experienced low spreading rates $(\sim 4 \mathrm{~mm} / \mathrm{y})$ during the rift evolution [Brune et al., 2014], which influenced the formation of narrow continental margins. Their model also suggests that these margins are magma-poor type and prone to the formation of hyper-extended crust. In contrast with the expressive knowledge accumulated for the adjacent regions of the study area, such as the Sergipe and Alagoas marginal basins [Mohriak and Rosendhal, 2003; Aslanian et al., 2009], the lack of geophysical data (seismic and nonseismic) has hampered a better understanding of the geotectonic evolution of the eastern border of the Borborema Province (BP in Figure 1). This research focuses on the three basins that formed in this marginal region: the Pernambuco Basin (PEB) and its distal portion formed by the Pernambuco Plateau (PEP), the Paraíba Basin (PAB), and the Natal Platform (NAP) [Magalhães et al., 2013; Buarque et al., 2016] (Figure 1).

Curie point depth (CPD) is the theoretical depth where most magnetic minerals lose their magnetic properties due to the increased temperature in the subsurface [Tanaka et al., 1999; Thébault et al., 2010]. The CPD obtained through the analysis of geomagnetic data can be used as a proxy for inferring the thermal characteristics of the crust (e.g., heat flow and geothermal gradient) [Tanaka et al., 1999; Ates et al., 2005; Bektas 2013; Hsieh et al., 2014; Li et al., 2013, 2017; Idarraga-García and Vargas, 2018; Aydemir et al., 2019; Gaudreau et al., 2019; Quintero et al., 2019]. CPD investigation is a complementary method to assess crustal characteristics that can be constrained by deep seismic surveys or heat flow and geothermal gradient data measured in boreholes [Ross et al., 2006; Li et al., 2010; Petrunin et al., 2013; Hsieh et al., 2014]. One of the applications of CPD estimation is the assessment of the relationship between the Moho surface (inferred crust-mantle boundary) and the CPD isotherm. Some studies have shown that the relationship between these two boundaries is complex, and the Curie isotherm can be shallower or deeper than the estimated Moho boundary. Therefore, the CPD-Moho relationship is influenced by the geotectonic context: continental shields [Maule et al., 2005; Guimarães et al., 2014; Leseane et al., 2015; Chopping et al 2015; Aboud et al., 2016], fold belts [Dolmaz et al., 2005; Rajaram et al., 2009), subduction zones [Manea and Manea, 2010; Hsieh et al., 2014; Manalo et al., 2016], volcano-tectonic zones [Bektaş et al., 2008; Bektaş, 2013]. Some works have also pointed out that CPD estimation represents a useful tool for the investigation on mantle magnetization, caused by serpentinization, beneath oceanic crust [Li et al., 2010, 2013; Ravat et al., 2011], continental shields and subduction zones [Blakely et al., 2005; Manea and Manea, 2011; Wang and Li, 2015].

\section{Geological setting}

The BP comprises the northeastern portion of the South American Platform [Almeida, 1981; Van Schmus et al., 2008; Santos et al., 2010; Araujo et al., 2013; Neves et al., 2015] (Figure 1) and is bounded to the south by the São Francisco Craton, to the west by the large intracratonic Parnaíba Basin, and to the north by the Potiguar, Ceará and Barreirinhas marginal basins [Matos, 1999; de Castro et al., 2012]. The BP consists of a complex combination of continental masses [Almeida et al., 1981; Santos et al., 2010], and its evolution involved a series of Precambrian orogenic events [Santos et al., 2010; Neves et al., 2012, 2015] and late rifting stages that culminated with a continental breakup during the Cretaceous [Chang et al., 1992; Matos, 1999]. The BP is divided into three main domains, or continental blocks, that are bounded by continental-scale shear zones: the Pernambuco-Alagoas Complex, known as the South Domain (SD); the central domain, known as the Transversal Zone (TZ), and the North Domain (ND) [Vauchez et al., 1995; Neves and Mariano, 1999; Brito Neves et al., 2002, Ferreira et al., 2008, Medeiros et al., 2011; Araujo et al., 2013; Neves et al., 2015] (Figures 1A and 1B). The most important shear zones within the BP are the Pernambuco Shear Zone (PESZ) and the Patos Shear Zone (PASZ), both trending mainly E-W and WSWENE (Figure 1). The formation of marginal basins was strongly controlled by this compartmentation of the BP and the large shear zones, which acted as boundaries to the studied basins (Figures 1 and 2) [Matos, 1999; Magalhães et al., 2013].

The studied area encompasses the Pernambuco, Paraíba and Natal Platform basins (Figures 1 and 2) [Mabesoone and Alheiros, 1993; Barbosa and Lima Filho, 2006; Barbosa et al., 2007; Magalhães et al., 2014b; Buarque et al., 2016]. 


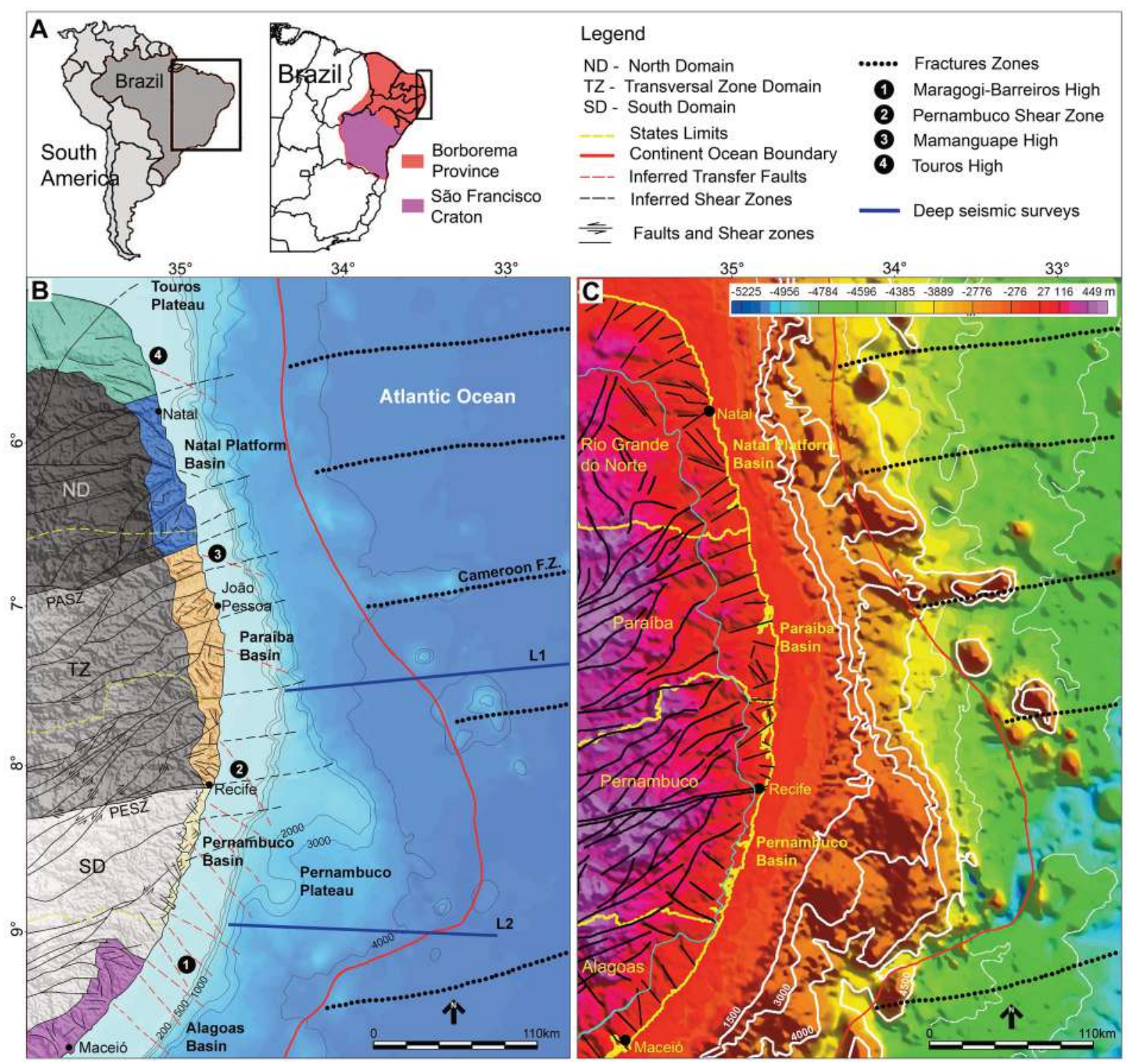

Figure 1. A) Location of the study area in northeastern Brazil and eastern portion of Borborema tectonic province. B) studied area formed by three marginal basins: Pernambuco, Paraíba and Natal Platform, and the adjacent continental basement. White numbers in black circles refer to boundaries between these basins. Purple, light-green, orange, blue, and dark-green areas represent the coastal zones of the marginal basins. The Red line indicates the position of the continent-ocean boundary [Magalhães et al. 2014a, 2014b]. Black dotted lines indicate major fracture zones. Dark blue lines (L1 and L2) represent the deep seismic sections that were used for the integration of geophysical transects. B) Topography and bathymetry of the studied area. The yellow line represent coastline and states boundaries. White lines indicate the isobaths. PESZ = Pernambuco Shear Zone, PASZ = Patos Shear Zone.

The continental breakup in this region is proposed at the Lower-Middle Albian [Matos, 1999; Almeida et al., 2005; Turner et al., 2008]. This segment of the Brazilian continental margin has been suggested to be a magma-poor margin type [Reston, 2009; Reston and Manatschal, 2011; Haupert et al., 2016]. Geophysical studies have indicated that the studied region is characterized by a narrow margin, probably formed by hyper-extended crust [Blaich et al., 2008; Magalhães et al., 2013]. The narrow extended margin was a consequence of the low spreading rates observed for this segment of the central South Atlantic $(\sim 30 \mathrm{~mm} / \mathrm{yr})$, in comparison to $>50 \mathrm{~mm} / \mathrm{yr}$ for the southeast margin of Brazil, around 120 m.y (Brune et al., 2016). This segment also presents an asymmetry in terms of extension compared to the African conjugate margins, which experienced more extension [Blaich et al., 2008; Aslanian et al., 2009; Brune et al., 2016]. 


\section{Jefferson Tavares Cruz Oliveira et al.}

The Pernambuco basin (PEB in Figure 1B) linked to the BP South Domain (SD) is separated from the Alagoas Basin to the south by the Maragogi-Barreiros High and from the Paraíba Basin (PAB in Figure 1B) to the north by the PESZ (Figure 1B). This basin exhibits a narrow coastal zone that was implanted over a narrow graben, which formed an interior basin, in the continental platform [Maia, 2012a; Barbosa et al., 2014; Buarque et al., 2016]. The platform break is marked by an outer hinge, the Maracatu High, which runs parallel to the coastline (Figure 2). The distal offshore region of PEB is mainly formed by the Pernambuco Plateau (PEP) [Fainstein and Milliman, 1979; Gomes, 2000; Oliveira, 2013], which developed over hyper-extended continental crust [Magalhães et al., 2014b] and extends to isobaths of approximately $4000 \mathrm{~m}$ (Figures 1 and 2). The PEP comprises at least four main basement lows and a central outer high, the Gaibu High (Figure 2). Another important outer high, the Itamaracá High, NWSE trending, is located on the northeastern border of the plateau (Figure 2).
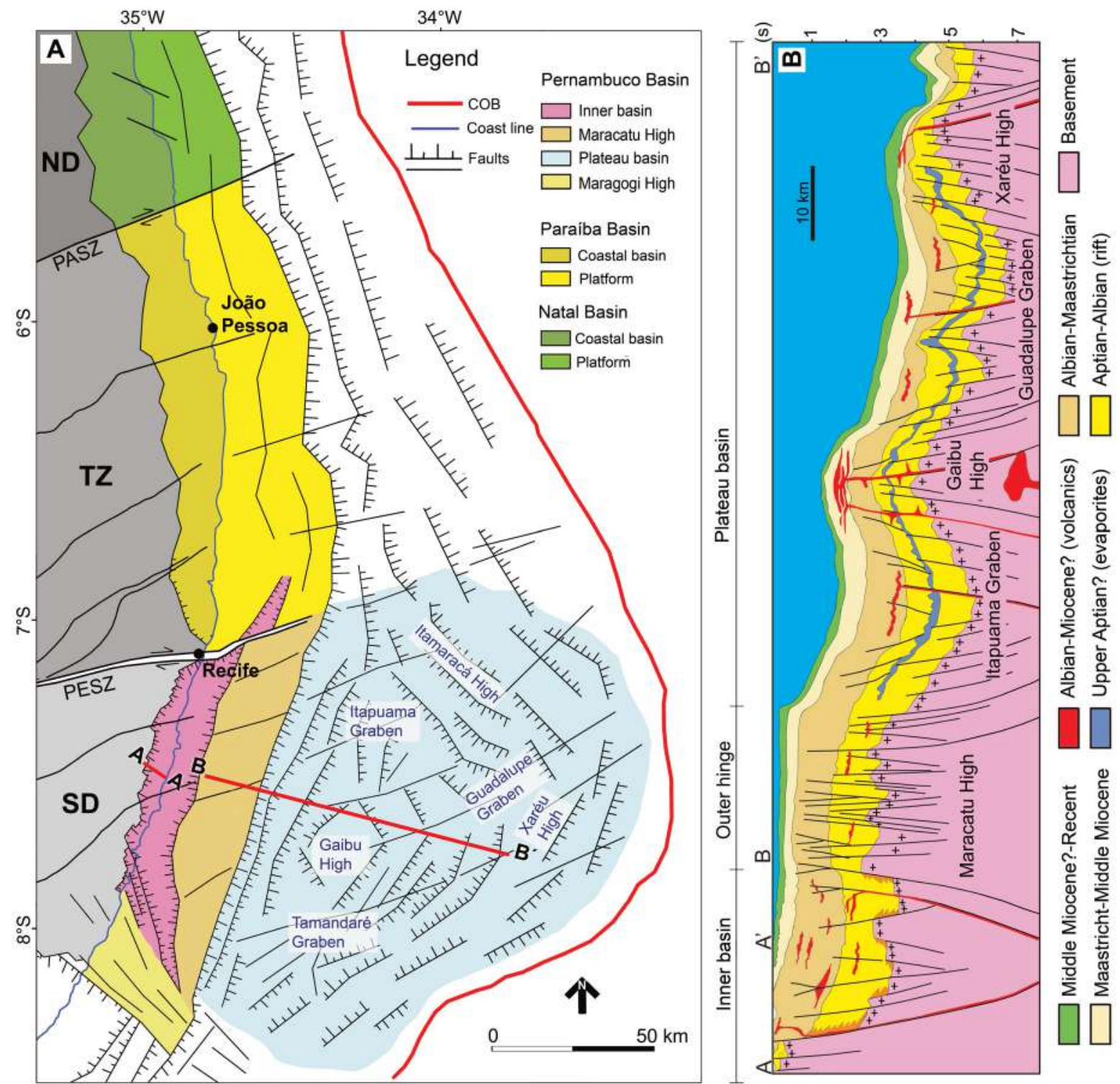

Figure 2. A) Structural map of marginal basins in the eastern sector of Brazilian margin and onshore Precambrian blocks of the Borborema Province (ND - North Domain, TZ Transversal Zone, SD - South Domain). The thin blue line represents the coastline; the thick red line represents the continent-ocean boundary [after Magalhães et al., 2013]; Red lines A-A' and B-B' represent 2D seismic sections. B) Integrated geological section based on seismic sections A-A' and B-B', showing the architecture of the Pernambuco Basin [modified from Buarque et al., 2016, 2017]. Depth is in time (seconds). 
The main sets of structures that controlled the PEB are mostly NE-SW- and E-W-trending ductile Precambrian shear zones, which have been reactivated as strike-slip and normal faults during the rifting process. Secondarily, there are oblique transfer faults trending NW-SE [Polônia, 1997; Lima Filho, 1998]. Additionally, normal faults trending N-S, WNW-ESE, and NNW-SSE, which formed during basin opening (Figures 1 and 2). The interpretation of seismic and potential field data has provided evidence of a significant sedimentary column in the plateau regions, which possibly reaches up to 6 to $7 \mathrm{~km}$ in thickness, over the main depocenters of the PEP [Oliveira, 2013; Magalhães et al., 2014a] (Figure 2B). The coastal zone of the Pernambuco Basin records a magmatic event that occurred during the Upper Albian and generated a series of volcanic rocks of the Ipojuca Magmatic Suite [Sial et al., 1988; Lima Filho, 1998; Nascimento, 2003] (Figure 2). The age of the main magmatic pulse is 102-103 My (Long et al., 1986 by Rb-Sr isochrons, and Nascimento, 2003 by $\mathrm{Ar}^{39} / \mathrm{Ar}^{40}$ zircon fission tracks). Buarque et al. [2016] proposed that this magmatic event continued in the PEP regions, forming extrusive and intrusive structures during the post-rift period (Figure 2B).

The Paraíba Basin (PAB in Figures 1 and 2) represents the second basin in the studied area and is linked to the TZ block of the BP. It is bounded by the two major shear zones PESZ to the south and the PASZ to the north (Figures 1 and 2). The PAB continental platform is narrow, with an abrupt shelf break. The maximum thickness of the sedimentary cover is approximately $0.4 \mathrm{~km}$ onshore, reaching a maximum of 1.5-2.0 km over the continental platform (Barbosa and Lima Filho, 2006; Lima Filho and Barbosa, 2010). The evolution of the PAB was controlled by Precambrian shear zones trending NE-SW, ENE-WSW, and E-W, which were reactivated as normal and oblique faults (Figs. 1 and 2). Secondarily, NW-SE-oriented transfer faults, and N-S- and NNW-SSE-trending normal faults formed during the basin opening (Barbosa and Lima Filho, 2006; Bezerra et al., 2014).

The Natal Platform Basin (NAP in Figure 1) is the northernmost marginal basin within the studied area and represents the narrowest continental margin sector (Figs. 1 and 2), with an even more abrupt shelf break (Lima Filho and Barbosa, 2010; Magalhães et al., 2014b). This basin is bounded to the south by the PASZ and to the north by the Touros High. This basin is related to the North Domain (ND) of BP (Figure 1B). Its onshore sedimentary cover reaches a maximum thickness of 0.25 to $0.4 \mathrm{~km}$, and offshore up to $2.0 \mathrm{~km}$ [Barbosa et al., 2007]. The evolution of NAP was controlled by Precambrian shear zones trending ENE-WSW and normal faults formed during the rift phase trending to WNW-ESE, NNW-SSE and N-S (Figures 1 and 2).

\section{Materials and methods}

The approach integrated the estimation of isostatic Moho accomplished through the processing of data obtained with satellite gravimetry missions and the estimated Curie depths map through the processing of airborne acquired magnetic data. This approach allowed us to observe the behavior of these two boundaries from the adjacent basement of the margin to the continent-ocean limits. Topographic and bathymetric data composed regional topography of the study area. The deep seismic profiles helped to constrain the behavior of the seismic basement and Moho, and the location and general characteristics of the crustal transition from the preserved continent zone to the oceanic domains.

\subsection{Satellite gravimetric dataset}

We have used regional Free-air and Bouguer gravity anomaly grids obtained from the Earth Gravitational Model (EGM 2008) through the National Geospatial-Intelligence Agency (NGA) [Pavilis et al., 2012]. EGM2008 is a spherical harmonic model of the Earth's gravitational potential, developed by a least-squares combination of the ITGGRACE03S gravitational model and its associated error covariance matrix [Pavlis et al., 2012]. This product represents a 1'x 1'equiangular global Bouguer anomaly grid which was computed by spherical harmonic analysis of global topography-bathymetry data (ETOPO 1), up to the degree and order of 10,800, and it has considered the boundaries and densities of largest lakes and interior seas, polar caps, and land areas below sea level [Balmino et al., 2011]. The topographic correction was computed with a distance of $167 \mathrm{~km}$, by using the 1'x 1' from the ETOPO1 elevation model. The value for correction density used for the Bouguer anomaly calculation was $2,670 \mathrm{~kg} / \mathrm{m} 3$ [Fullea et al., 2008; Balmino et al. 2011]. The processing of these datasets provided the free-air, Bouguer, and regional topography maps used in this research (Figures 1C, 3A, and 3B). 

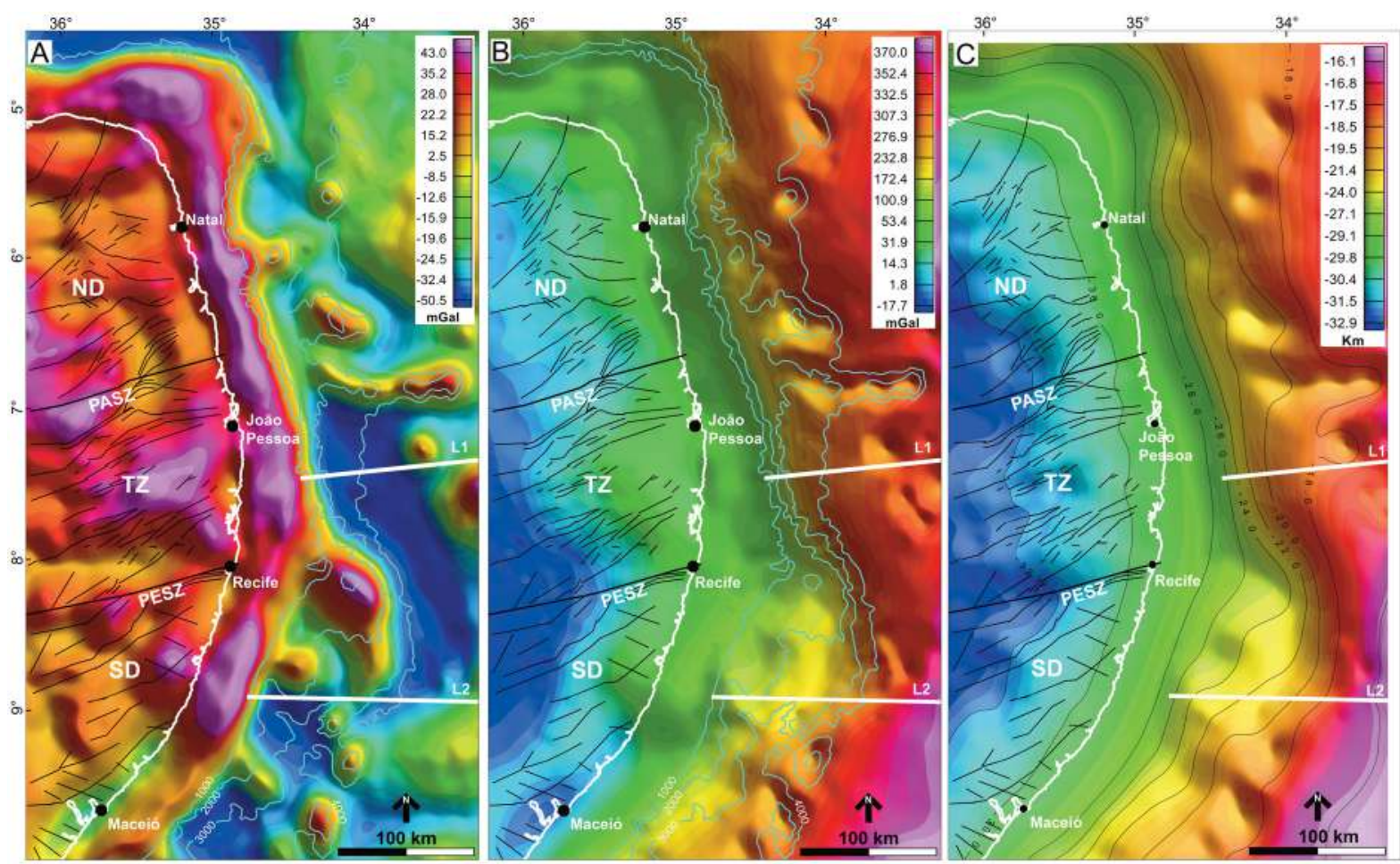

Figure 3. Free-air (A) and Bouguer (B) gravity anomaly and isostatic Moho depth (C) maps elaborated on the NE Brazilian marginal basins derived from satellite data. White line: coastline; light blue lines: bathymetry; thin black lines: main faults and shear zones in continental domains. White lines (L1 and L2) represent 2D deep seismic sections used to build integrated geophysical transects (Figures 9 and 10). Domains of the BP: SD: South Domain; TZ: Transversal Zone; ND: North Domain.

\subsection{Isostatic Moho}

The isostatic Mohorovičić (Moho) discontinuity depth map (Figure 3C) is elaborated by isostatic modeling of the topographic load on the lithospheric plate using the Airy-Heiskanen isostatic compensation model [Heiskanen and Moritz, 1967]. The calculation requires the estimation of three parameters, a depth compensation for sea-level elevation $d s$, a density contrast along the bottom of the root load $\Delta \rho$, and the density of the topographic load $\rho t$ [Simpson et al., 1986]:

$$
d=d s+e\left(\frac{\rho t}{\Delta \rho}\right)
$$

where elevation $e$ represents the elevation of the topographic surface. In oceanic crustal domains, the water column represents a negative load at the top due to the presence of water density:

$$
d=d s-d w\left(\frac{\rho t-\rho w}{\Delta \rho}\right)
$$

Thus, $d w$ represents the bathymetry, and $p w$ represents the density of seawater.

The crustal thickness $(d s)$ of $30 \mathrm{~km}$ we used for the zone between onshore and offshore regions was based on an estimation made by previous works using seismic and potential field methods data, which showed that the average thickness in the narrow coastal zones of studied margins is about 30-32 km [Lima et al., 2015; Oliveira and Medeiros, 2012]. The other parameters were based on Moho depths estimated by Blaich et al. [2008, 2011], and Magalhães et 


\section{CPD Unveil NE Brazilian Margin Framework}

al. [2014b], for marginal basins of NE Brazil: density of water, $\rho w=1.03 \mathrm{~g} / \mathrm{cm}^{3}$, the density of uniform crust (basement rocks and sediment cover), $\rho t=2.67 \mathrm{~g} / \mathrm{cm}^{3}$, and the contrast at the base of the interface crust-mantle, $\Delta \rho=0.45$ $\mathrm{g} / \mathrm{cm}^{3}$. We assume a density for lithospheric mantle $=3.3 \mathrm{~g} / \mathrm{cm}^{3}$

Estimated isostatic Moho depths in the continental region adjacent to marginal basins present values ranging from 29 to $35 \mathrm{~km}$ (Figure 3C), which is consistent with values of isostatic Moho depth found by Lima et al. [2015] based on seismic refraction data analysis, and Oliveira and Medeiros [2012], based on gravimetric data.

\subsection{Airborne magnetic dataset}

The dataset used in this study (Figure 4) represents an integration of four airborne magnetic surveys obtained from the Exploration and Production data repository (BDEP) of the Brazilian National Agency of Petroleum, Natural Gas and Biofuels (ANP), and from the Brazilian Geological Survey (CPRM). Each dataset was processed separately before integration. The Plataforma Continental Nordeste survey (S1) was concluded in 1970 with NE-SW-oriented flight lines, a spacing of $5 \mathrm{~km}$, and flight height of $700 \mathrm{~m}$. The LASA company acquired the Platô de Pernambuco survey (S2) 1988 with NW-SE (N30 ${ }^{\circ}$ W)-oriented flight lines, a spacing of $3 \mathrm{~km}$, and a flight height of $500 \mathrm{~m}$. The Maragogi-Canavieiras survey (S3) was concluded in 1986 with NW-SE (N30 ${ }^{\circ} \mathrm{W}$ )-oriented flight lines, a spacing of $3 \mathrm{~km}$, and flight height of $500 \mathrm{~m}$. The Projeto Aerogeofísico da Borda Leste do Planalto da Borborema survey (S4), which covers the BP basement adjacent to the eastern margin, was carried out in 2007, with N-S-oriented flight lines spaced $500 \mathrm{~m}, \mathrm{E}-\mathrm{W}$-oriented control lines spaced $10 \mathrm{~km}$, and a flight height of $100 \mathrm{~m}$. Furthermore, the International Geomagnetic Reference Field (IGRF) was subtracted from each dataset separately considering their period of acquisition (1970 - S1, 1985 - S2 and S3, 2005 - S4) using the Oais-Montaj software. The four surveys were interpolated using the bidirectional gridding method with a $750 \mathrm{~m}$ cell size.

The data processing included spike removal, microleveling, and upward continuation. The airborne magnetic data were leveled using directional cosine and Butterworth filters to attenuate leveling artifacts [Johnson et al., 1999]. We have integrated the four grids by considering an altitude of $700 \mathrm{~m}$, which was achieved by using the upward continuation technique in surveys S2, S3, and S4. Thus, by considering the overlapping of the four survey areas we chose the suture method to merge the grids [Johnson et al., 1999]. The merged total magnetic intensity (TMI) map covers the northeastern most Brazilian continental platform region to the 2,000 to 3,000 $\mathrm{m}$ isobaths and most of the PEP domains (Figures 4A and 4B) to the isobaths at 4,000 to 5,000 m. This map also covers 80 to $100 \mathrm{~km}$ of the adjacent onshore basement formed by the $\mathrm{BP}$, which allowed us to analyze the transition between the preserved and the extended segments of the continental crust.

\subsection{Curie Point Depth (CPD) estimation}

The estimation of CPD can be based on an analysis of airborne magnetic data as proposed by Bhattacharyya and Leu [1965, 1975a, 1975b, 1977], Spector and Grant [1970], and Okubo et al. [1985], and Tanaka et al. [1999]. According to this method, the magnetic anomalies are divided into rectangular regions, for which the depths of the top $\left(Z_{\mathrm{t}}\right)$ and centroid $\left(Z_{0}\right)$ of the magnetic sources can be defined by using the logarithm of the power spectrum. The depth to the bottom $\left(Z_{\mathrm{b}}\right)$ can be deduced from $Z_{\mathrm{t}}$ and $Z_{0}$ [Okubo et al., 1985]. The analysis is based on three main steps: 1 - the division of data in overlapping squared windows; 2 - the calculation of the radially averaged logarithm of the power spectrum for each window; and 3 - the estimation of the CPD from the calculation of the centroid and top depths of the magnetic source for each subregion. The upper limit of a magnetic source is assumed to feature a vertical dimension that is far smaller than the magnetic source's horizontal dimension, and the magnetization $M(x, y)$ is a random function of $x$ and $y$ [Spector and Grant, 1970; Bhattacharyya and Leu 1975b, 1977]. Furthermore, according to the model that was proposed by Blakely [1995], the power density spectra of the observed magnetic anomaly $\phi_{\Delta T}$ is given by:

$$
\phi_{\Delta T}\left(k_{x}, k_{y}\right)=\phi_{M}\left(k_{x}, k_{y}\right) \cdot F\left(k_{x}, k_{y}\right)
$$


Jefferson Tavares Cruz Oliveira et al.

$$
F\left(k_{x}, k_{y}\right)=4 \pi^{2} C_{m}^{2}\left|\Theta_{m}\right|^{2}\left|\Theta_{\mathrm{f}}\right|^{2} e^{-2|k| Z_{t}}\left(1-e^{-|k|\left(Z_{b}-Z_{t}\right)}\right)^{2}
$$

where $\phi_{M}$ is the power density spectrum of the magnetization; $C_{m}$ is a proportionality constant; and $\Theta_{m}$ and $\Theta_{f}$ represent the magnetization direction and geomagnetic field direction, respectively. We can simplify this equation by considering that all the terms except $\left|\Theta_{m}\right|^{2}$ and $\left.\Theta_{f}\right|^{2}$ are radially symmetric, that the radial average measures of $\Theta_{m}$ and $\Theta_{f}$ are constant, and that $M(x, y)$ is constant for random and uncorrelated source distributions. Therefore, we can postulate that $\Phi_{\mathrm{M}}\left(\mathrm{k}_{\mathrm{x}}, \mathrm{k}_{\mathrm{y}}\right)$ is constant. Thus, the radial average of $\Phi_{\Delta T}$ is given by

$$
\phi_{\Delta T}(|k|)=A e^{-2|k| Z_{t}}\left(1-e^{-|k|\left[Z_{b}-Z_{t}\right)^{2}}\right)
$$

where $\mathrm{A}$ is a constant and $\mathrm{k}$ is the wavenumber.
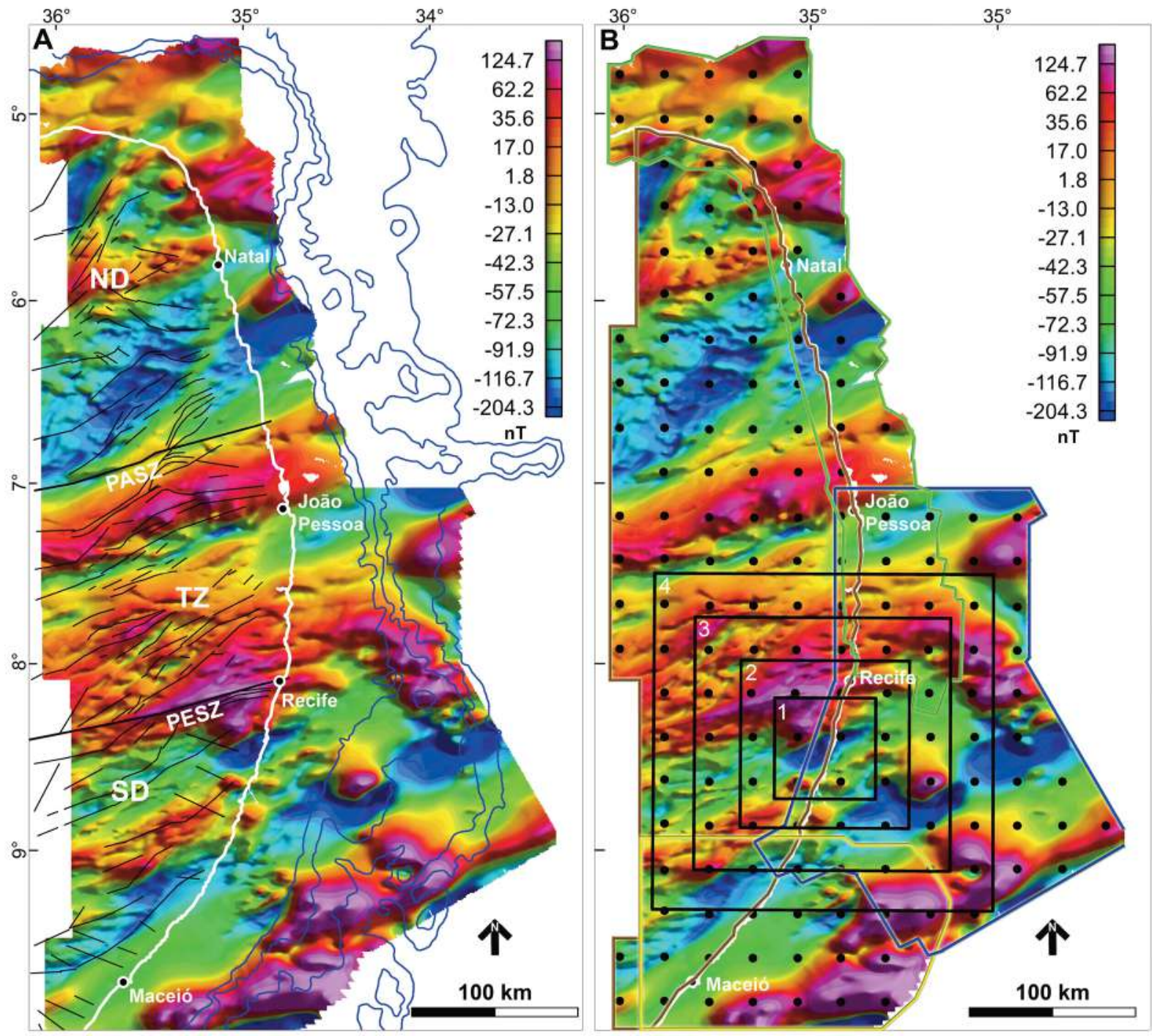

Figure 4. A) Airborne total magnetic intensity (TMI) map of the NE Brazilian marginal basins created by the integration of 4 aeromagnetic surveys (S1, S2, S3, and S4). B) TMI map with locations of the CPDs, and representation of square windows used in the test of spectral analysis $(50,100,150,200 \mathrm{~km})$, numbered 1 to 4, respectively. The green polygon indicates the S1 survey area, blue polygon = S2 survey area, yellow polygon = S3 survey area, and brown polygon $=$ S4 survey area. 


\section{CPD Unveil NE Brazilian Margin Framework}

For very thick magnetic bodies, the second part of Equation 4 is used to define only the top depth, so Equation 5 can be reduced to

$$
\ln \left[\phi_{\Delta T}(|k|)^{1 / 2}\right]=\ln B-|k| Z_{t}
$$

where $B$ represents a constant. Thus, the upper limit of the studied magnetic source $Z_{t}$ can be estimated by assuming that the signals from the source tops dominate the power spectrum.

Equation 5 can be further simplified to compute the centroid depth $\mathrm{Z}_{0}$ of the magnetic source from the long wavelengths, or the low-frequency portion of the power spectrum:

$$
\ln \left\{\frac{\phi_{\Delta T}(|k|)^{1 / 2}}{|k|}\right\}=\ln C-k Z_{0}
$$

Thus, the slope of the average amplitude spectrum allows us to estimate the top and centroid of the magnetic body by tracing straight lines over the curve of the radially averaged power spectrum, dividing the area into two trends. The short wavelengths, or high frequencies, indicate the top depth of the body, and the long wavelengths, or low frequencies, mark the depth positions of the centroid [Okubo et al., 1985; Tanaka et al., 1999]. This information is obtained from Equations 6 and 7; hence, the depth of the lower limit of the magnetic body, $\mathrm{Z}_{\mathrm{b}}$, which is assumed to be the depth at which the minerals lost their ferromagnetic properties, possibly the CPD [Okubo et al., 1985; Okubo and Tsu, 1992], can be obtained from Equation 8 (Figure 5A):

$$
Z_{b}=2 Z_{0}-Z_{t}
$$

The power spectrum was computed by using a 2D fast Fourier transform. We have determined the depth of the centroid, $Z_{0}$, and the depth of the top, $Z_{t}$, of the magnetic sources via two trends: 1 - the slopes of the frequencyscaled power spectrum; and 2 - the average amplitude spectrum for the deep sources from the first segment and the shallow sources from the second segment. We use the wavenumber range of 0.005 to $0.04 \mathrm{rad} / \mathrm{km}$ for the calculation of $Z_{0}$, and 0.04 to $0.10 \mathrm{rad} / \mathrm{km}$ for the $Z_{t}$.

\subsubsection{Window size}

An important debate about the CPD estimation involves the definition of the effective width of the sampling window, which is an essential part of the centroid method [Bouligand et al., 2009; Li et al., 2010; Abraham et al., 2014a, 2014b; Nwankwo and Shehu, 2015]. Some authors argue that large square windows are necessary to ensure that the response of the deepest magnetic layers is captured and that the use of windows with small widths cannot efficiently resolve deep sources. Previous works have proposed that an optimal square window dimension is approximately 10 [Chiozzi et al., 2005; Ravat et al., 2007] or 10 to 15 [Bouligand et al., 2009; Chopping and Kennet, 2015] times the expected bottom depth of the deepest magnetic layers. In general, the Curie isotherm is expected to be above or near the Moho [Salem et al., 2014]. However, the position of the bottom of the magnetic layer can vary significantly according to the geotectonic context. In thinned lithospheric regions which experienced higher geothermal gradients and heat flow in the mantle lithosphere, it is expected that the Curie isotherm is shallower than the Moho [Maule et al., 2005; Jaupart and Mareschal, 2007; Thébault et al., 2010; Salem et al., 2014; Leseane et al., 2015]. In regions where the mantle is magnetized the Curie isotherm can be below the Moho [Li et al., 2016]. According to Magalhães et al. [2014b], and our calculation of the isostatic Moho depth, the crustal thickness at the proximal region of the studied basins, near the coastline, is approximately $30 \mathrm{~km}$. The crustal thickness is reduced along the margin and reached approximately $10-12 \mathrm{~km}$ in the continent-ocean boundary. The crustal thickness in the adjacent basement (BP) of the studied margin varies from 30 to $35 \mathrm{~km}$, which is in accordance with the analysis of deep seismic refraction data [Lima et al., 2015].

To ensure the optimal size of the window sampling we performed a test with a single point in the central region of the PEP with four different square windows (50 x 50, $100 \times 100,150 \times 150,200 \times 200 \mathrm{~km}^{2}$ ) (Figure 4B). The test showed that the detection of the depth to the base of the magnetic signal stabilizes in windows greater 

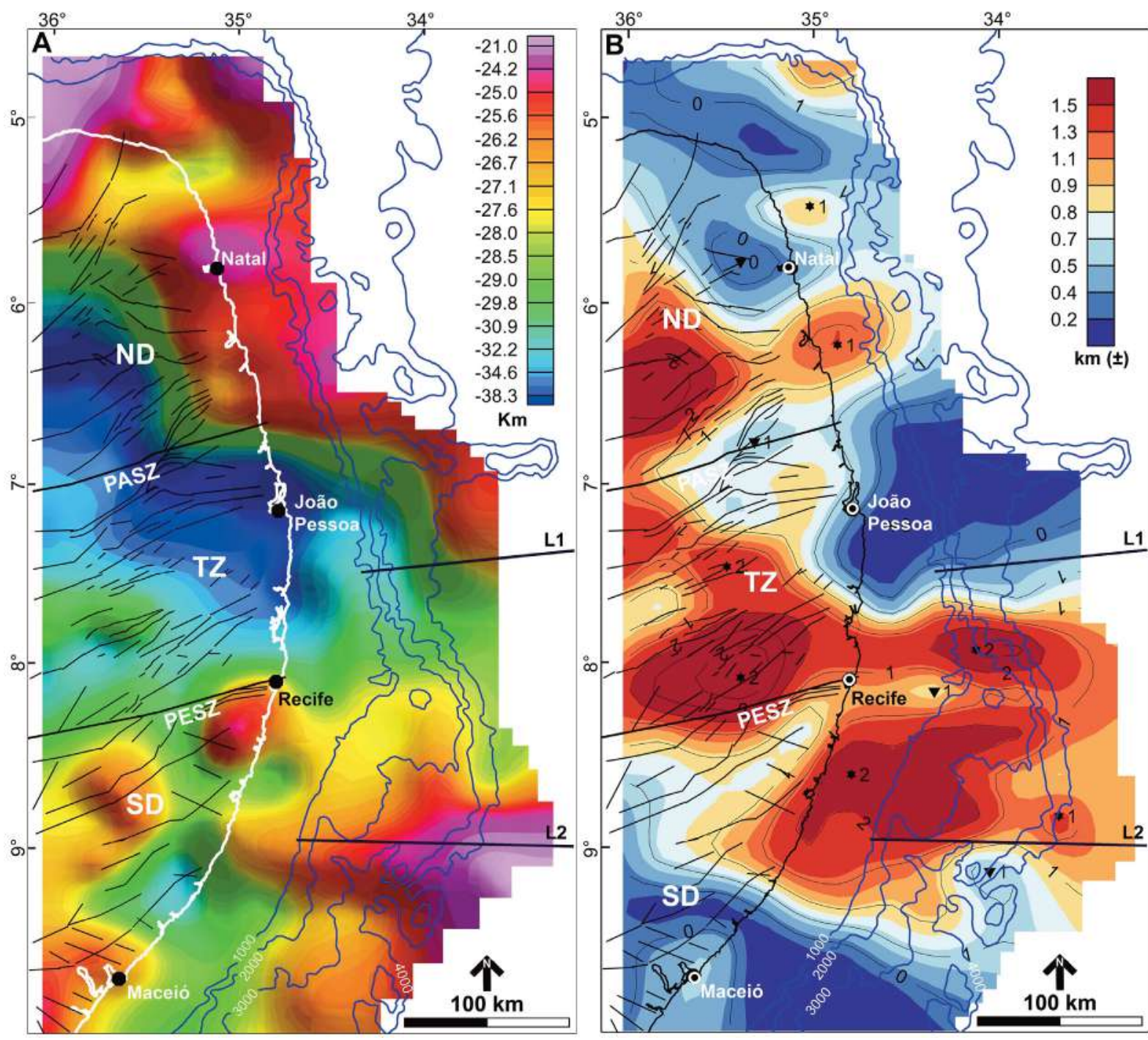

Figure 5. A) Curie point depth map of the studied region. B) Map of the estimated error for the value of the base of the magnetic layer (Z0). Black lines in the adjacent continental zone represent major faults and shear zones. Light blue lines represent the bathymetry. Black lines (L1 and L2) represent 2D deep seismic sections used for integration with geophysical maps. Domains of the BP: SD: South Domain; TZ: Transversal Zone; ND: North Domain. Blue lines represents isobaths.

than $150 \mathrm{~km}$ (Table 1), which suggests that it represents a window size capable of resolve the detection of the bottom of the magnetic layer. Thus, we choose the square window of $150 \mathrm{~km}$ to perform the spectral analysis. We divided the magnetic map into 162 overlapping 150-km-wide square windows (Figure 4B). The rate of overlap between the windows was $75 \%$. After the distribution of the sampling area centers, windows with more than $\sim 25 \%$ missing data, such as some windows near the boundaries of the map, were removed to avoid errors and artifacts. The chosen sampling window size was the same used to perform the analysis of the Curie depths in the BP through the spectral analysis of airborne magnetic data [Correa et al., 2016]. The estimated crustal thickness of BP varies from 25 to $>45 \mathrm{~km}$ [Correa et al., 2016]. 
CPD Unveil NE Brazilian Margin Framework

\begin{tabular}{ccc}
50 & 2.48 & 20.03 \\
\hline 100 & 3.81 & 26.66 \\
\hline 150 & 5.89 & 34.13 \\
\hline 200 & 6.67 & 34.16 \\
\hline
\end{tabular}

Table 1. Values of $\mathrm{Zt}$ (top) and $\mathrm{Zb}$ (bottom) of the magnetic layer according to the window size sampling showed in Figure $4 \mathrm{~B}$, from 1 to 4 , respectively.

\subsubsection{CPD Uncertainty Control}

We have performed a statistical evaluation of obtained $Z_{0}$ values, which is important to define the error generated by the range of wavenumber in the analyzed spectrum because the error is expected to be higher where the wavenumber is lower. The error estimation [Okubo and Matsunaga, 1994] is calculated based on the misfit between the radially calculated spectrum $\left(\mathrm{K}_{\text {calculated }}\right)$ and the straight line obtained through the numerical adjustment ( $\mathrm{K}_{\text {theoretical }}$ (Eqs. 6 and 7). Thus, the misfit (R) is calculated was calculated with Equation 9:

$$
R=\sqrt{\frac{1}{N} \sum_{k}\left(K_{\text {Calculated }}-K_{\text {Theoretcal }}\right)^{2}}
$$

where $\mathrm{N}$ is the number of points in the calculated spectrum. The map showing the error for the CPD estimation is shown in Figure 5B.

\subsubsection{Geothermal gradient (GG) and heat flow (HF)}

After calculating the CPD, we proceed to obtain the geothermal gradient (GG), which can be estimated from the variation between a given $\mathrm{CPD}$, where the local temperature is assumed to be $\sim 580{ }^{\circ} \mathrm{C}$, and the temperature at the Earth's surface by considering a vertical direction and the distance between them [Eppelbaum et al., 2014]. In this case, we have not considered the effect of radiogenic heat. We have considered the value of $5^{\circ} \mathrm{C}$ for the surface temperature in the offshore region, according to Beardsmore and Cull [2001]. This estimation is obtained by considering the relationship between the depth of the seabed, and the latitude of a given marine region, with an error of $\pm 2^{\circ} \mathrm{C}$. The same value was considered by Li et al. [2017] for oceanic regions to build a global CPD model. We have considered $5^{\circ} \mathrm{C}$ also as the surface temperature of the continental region because the estimate of this parameter for large onshore sectors is very complex due to the many aspects that control this information (altitude, climate, and lithology). The GG distribution was then obtained through Equation 10:

$$
\frac{\partial T}{\partial Z}=\frac{\Delta T}{\Delta Z}=\frac{580^{\circ} \mathrm{C}-5^{\circ} \mathrm{C}}{Z_{b}}
$$

After estimating the GG values in ${ }^{\circ} \mathrm{C} / \mathrm{m}$, we estimated the heat flow (HF) values by applying Equation 11:

$$
q=-\lambda \frac{\partial T}{\partial Z}
$$

where $\mathrm{q}$ represents the $\mathrm{HF}$, given in $\mathrm{mW} / \mathrm{m}^{2} ; \lambda$ represents the thermal conductivity constant $\left(\mathrm{W} / \mathrm{m}^{\circ} \mathrm{C}\right)$; and $\frac{\partial T}{\partial Z}$ represents the $\mathrm{GG}\left({ }^{\circ} \mathrm{C} / \mathrm{m}\right)$. Due to the lack of information about the conductivity properties of the crust in the 


\section{Jefferson Tavares Cruz Oliveira et al.}

offshore studied regions, we have adopted the proposition of Kappelmeyer and Haenel [1974], who proposed a general estimation for the conductivity of the Earth's crust with a factor range between 2 to $2.5 \mathrm{~W} / \mathrm{m}^{\circ} \mathrm{C}$. Thus, we assume an intermediate value for $\lambda$ of $2.25 \mathrm{~W} / \mathrm{m}^{\circ} \mathrm{C}$ [Eppelbaum et al., 2014].
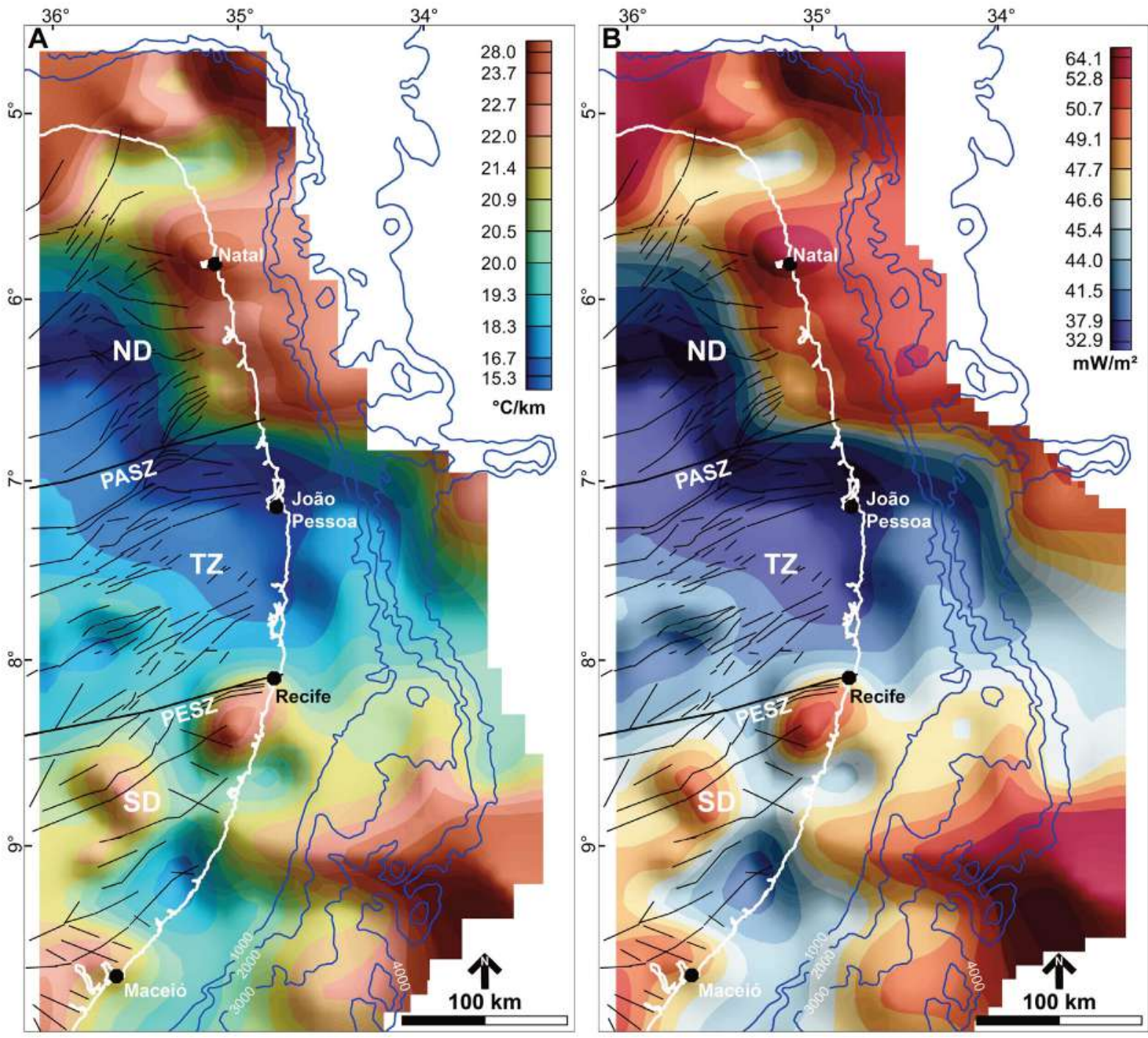

Figure 6. A) Geothermal gradient map calculated after the estimation of the CPD in the study area. B) Heat flow map estimated for the studied region. Black lines in the adjacent continental zone represent major faults and shear zones. Blue lines represent the bathymetry. Domains of the BP: SD: South Domain; TZ: Transversal Zone; ND: North Domain. Blue lines represents isobaths. 
After the calculation of GG and HF estimates, based on the 162 CPD points, the data were interpolated in a 30km-spaced grid to produce GG and HF maps (Figure 6A and 6B). To evaluate the CPD derived GG and HF data, we have used heat flow data from 20 wells located in the onshore and offshore domains of the studied area available in the global heat flow database of the International Heat Flow Commission (IHFC, 2018) for comparison and further discussion (Figure 7).

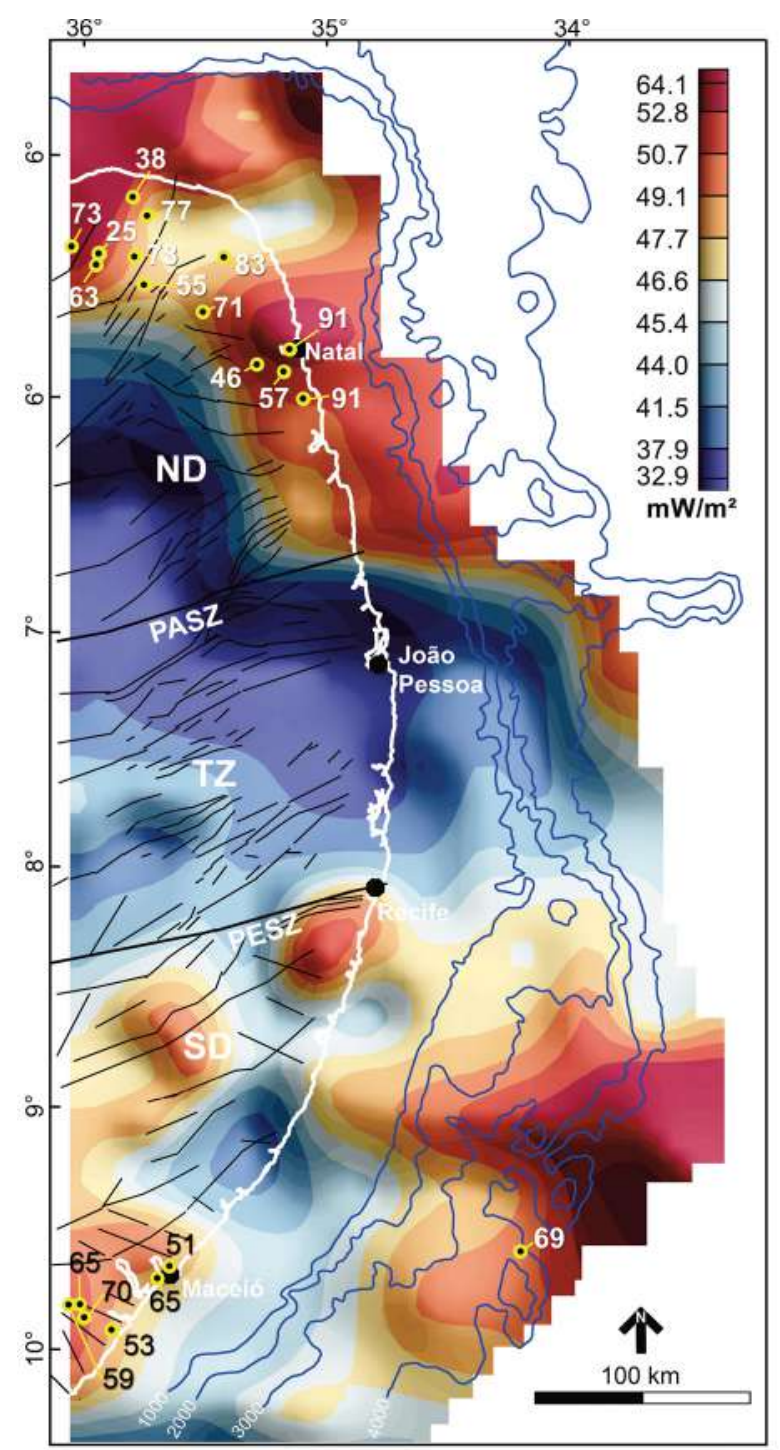

Figure 7. Heat flow (HF) map of the NE Brazilian marginal basins with locations of the HF measurements in exploratory wells (IHFC, 2018). Yellow dots mark boreholes, and the numbers indicate the heat flow measurements in $\mathrm{mW} / \mathrm{m}^{2}$. 


\section{Jefferson Tavares Cruz Oliveira et al.}

\subsection{D Multichannel seismic dataset}

A set of 143 2D multichannel, time-migrated, seismic sections was studied to define some of the main tectonic characteristics of the region (Figure 8A). The data was obtained from the BDEP-ANP. The seismic surveys consist of a variety of legacy seismic data with different qualities and imaging depths ( $8 \mathrm{~s}$ to $11 \mathrm{~s}$ ), representing a total length of $10,360 \mathrm{~km}$. Interpretation of the surveys allowed the creation of a contour map of the seismic basement with the depth in time (TWT), and we have created a second version with the depth in meters (Figure 8B). Due to the lack of offshore wells, a simple layer-to-layer velocity model was used for the depth conversion. We have considered estimations of the velocities for the three main sequences interpreted in seismic data (rift, Cretaceous post-rift, Cenozoic post-rift) (Figure 2B). For the time-to-depth conversion, we have used velocities described for similar sequences in wells from the neighbor Alagoas Basin (Figure 8). The estimation of basement depth and its topography, as well as the thickness of the sedimentary cover, was used to help to estimate the crustal properties in the studied region, especially for the Pernambuco Plateau region and Paraíba Basin (Figs. 9 and 10).
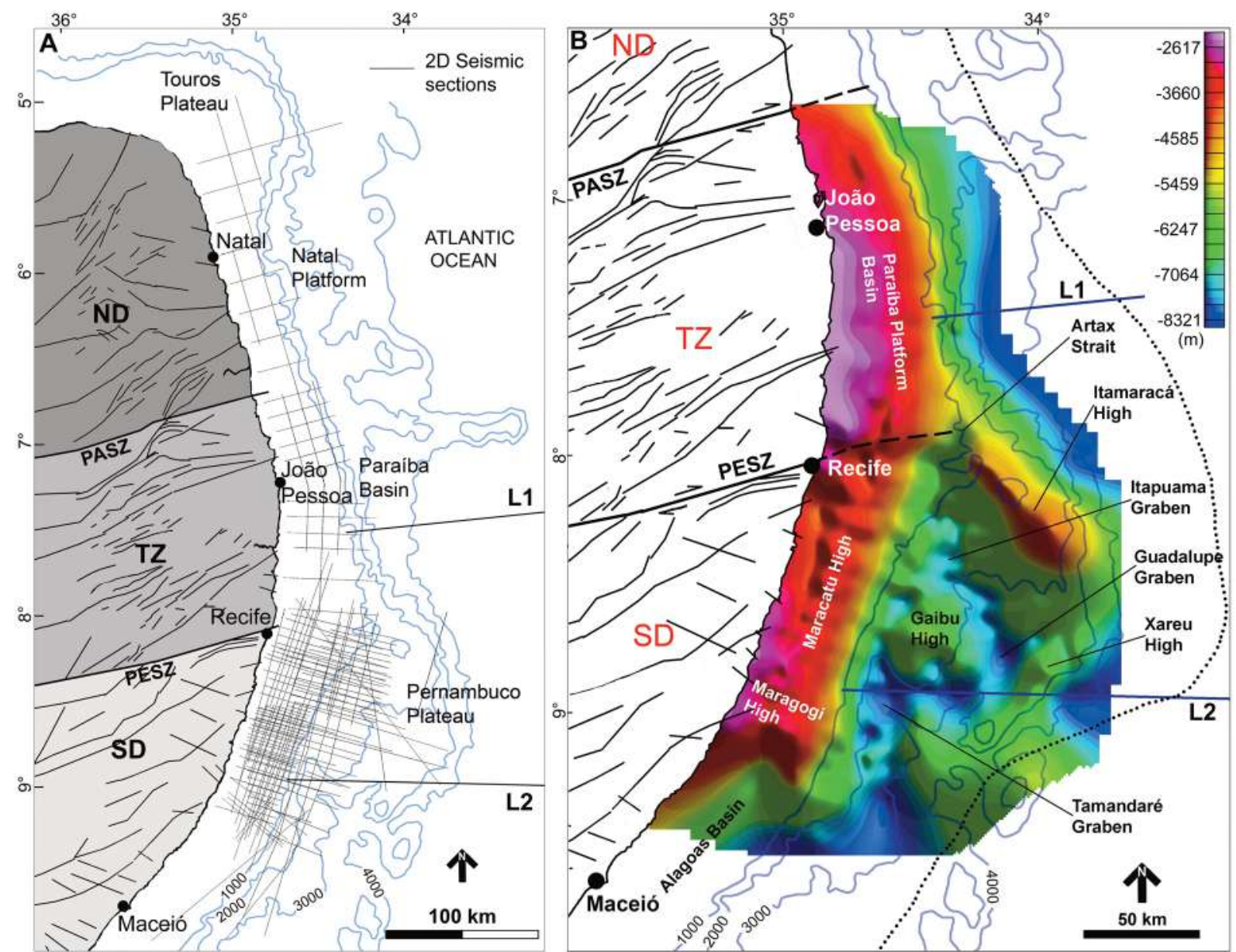

Figure 8. A) Distribution of 143 2D multichannel seismic sections (grey lines) used to interpret the basement contour and the sedimentary cover in the Pernambuco and Paraíba basins. Black lines represent major continental shear zones and faults; light blue lines represent bathymetry, B) Depth to basement map that shows the main structural domains of the Pernambuco Basin and the Paraíba Platform. The dotted black line marks the interpreted limit of the continent-ocean boundary [Magalhães et al., 2013]. The dashed black line indicates the extension of PESZ to the platform. Blue lines represent isobaths at 200 m, 2000 m, 3000 m, and 4000. Structures in the continent: thin black lines: lineaments. L1 and L2 represent regional deep seismic sections used to create the geophysical transects. 


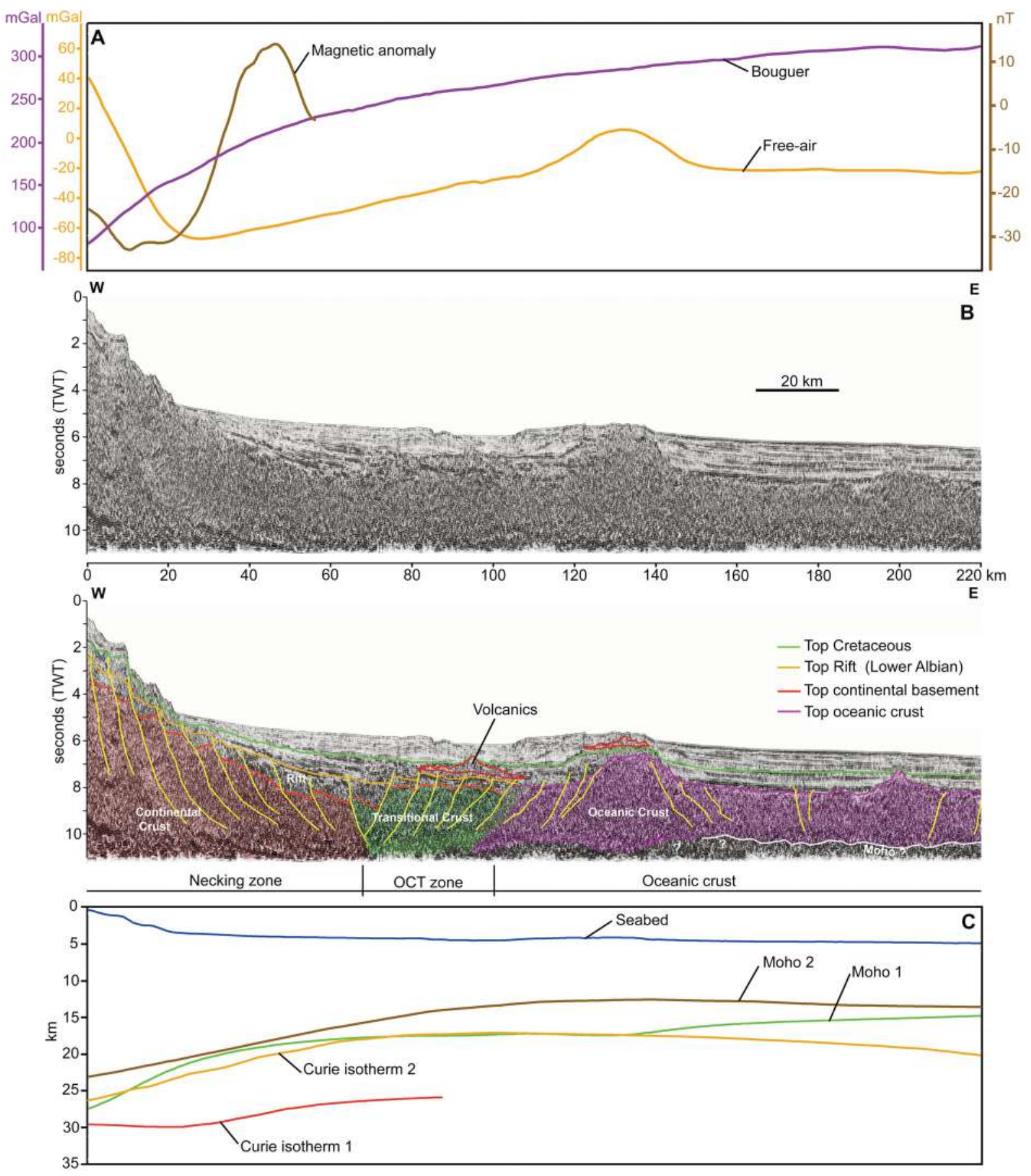

Figure 9. Geophysical transect L1. A) Gravity and magnetic anomalies, B Non-interpreted, and interpreted seismic sections located in the offshore distal region of the PAB, C) isostatic Moho, and CPD surface. Moho $1=$ isostatic Moho estimated in this research, Moho 2 = crust-mantle boundary extracted from the global earth crust thickness project Crust 1.0, Curie surface $1=$ CPD estimated by the present research, Curie surface $2=$ CPD extracted from the CPD global model of Li et al. [2017]. 

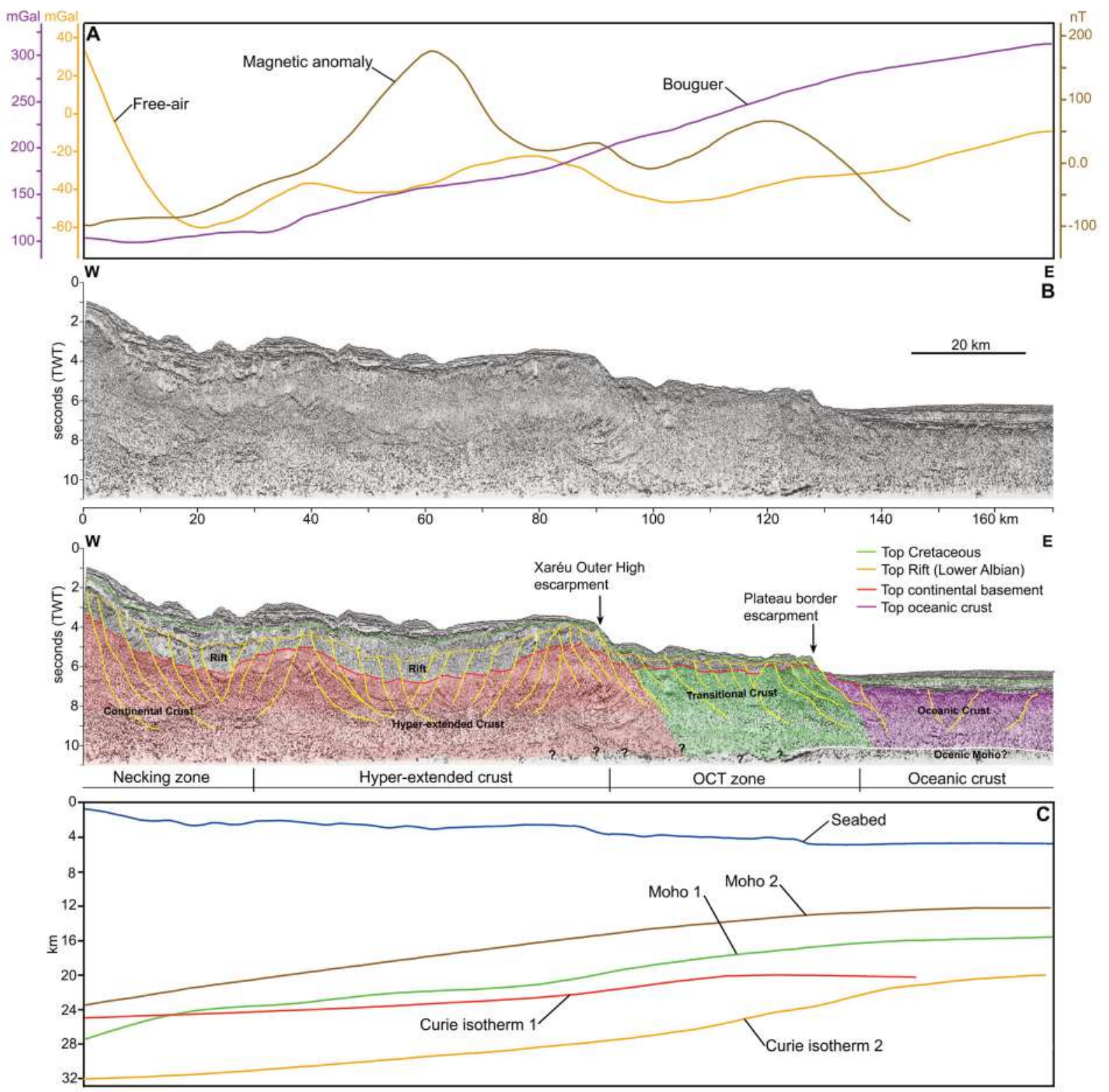

Figure 10. Geophysical transect L2. A) Gravity and magnetic anomalies, B) Non-interpreted and interpreted seismic sections located in the offshore distal region of Pernambuco Basin, C) Isostatic Moho, and CPD surface. Moho 1 = isostatic Moho estimated in this research, Moho 2 = crust-mantle boundary extracted from the global earth's crust thickness project Crust 1.0, Curie surface $1=$ CPD estimated by the present research, Curie surface $2=\mathrm{CPD}$ extracted from the CPD global model of Li et al. (2017). 


\section{CPD Unveil NE Brazilian Margin Framework}

\subsection{Integrated 2D geophysical transects}

Two regional 2D multichannel, time-migrated, deep seismic sections (11 s TWT) acquired by the Brazilian Navy LEPLAC Program were also integrated into the dataset to define the characteristics of the crustal transition in the north and south sectors of the studied margin. The seismic sections (L1 and L2 in Figure 9B and 10B) are 170 and $220 \mathrm{~km}$ long, respectively. Interpretation of these sections was integrated with gravity and magnetic anomalies to improve the characterization of crustal domains.

We have compared the estimation projected by this research about the Moho topography and the Curie isotherm with data from global models calculated with satellite-based gravity and magnetic surveys, and seismic data. Data from the global model Crust 1.0, earth's crust thickness, were collected and plotted in the L1 and L2 transects. Crust 1.0 represents a crustal thickness model based on a grid of $1^{\circ}$ cell size calculated from active source seismic studies and receiver function studies and constrained with gravity data (https://igppweb.ucsd.edu/ gabi/crust1.html). This model followed the same procedures applied to the creation of the earth's crust model CRUST 2.0 [Tenzer et al., 2009; Reguzzoni et al., 2013]. We have also extracted data points from the global model of CPD provided by Li et al. [2017]. This model represents a global 10'cell-size grid with the estimation of Curie isotherm calculated with the fractal magnetization method that used the global magnetic field anomaly model EMAG2. This approach used three sampling windows with a size of $98.8 \times 98.8$ $\mathrm{km}^{2}, 195 \times 195 \mathrm{~km}^{2}$, and $296.4 \times 296.4 \mathrm{~km}^{2}$. The final grid represents the average CPD obtained from the three windows for each sampled zone. We have plotted data of CPD from this model in the L1 and L2 transects (Figures 9 and 10) for comparison with our results.

\section{Results}

\subsection{Crustal thermal properties}

The CPD values in the studied margin vary from 21 to $38 \mathrm{~km}$, and they are deeper in the continental region and shallower towards the oceanic region. The TZ continental block shows the main concentration of deepest CPDs, which varied from 35 to $29 \mathrm{~km}$. The shallower CPD values are related to the two plateaus located to the north, Touros, and to the south, Pernambuco, limits of the studied region.

The southern sector of the studied area, that represents the PEB and its plateau, as well the southern limits between the PEB and Alagoas basins, exhibits CPD values varying from 32 to $26 \mathrm{~km}$ (Figure 5A) in the continental region. In the offshore region of PEB the CPD values vary from 28 to $23 \mathrm{~km}$. The northern part of the PEP exhibits values varying from 28 to $25 \mathrm{~km}$ (Figure 5A). The southern part of the plateau presents CPD values ranging from 25 to $21 \mathrm{~km}$, with shallower values in the southeast border. The CPD isotherm is roughly oriented ENE-WSW and E-W (Figure 5A). The central block of BP (TZ in Figs 5 and 6), bounded by the PASZ and PESZ, shows deeper CPD values, ranging from 38 to $29 \mathrm{~km}$. CPD in the marginal region, which represents the domains of the PAB, ranges from 39 to $28 \mathrm{~km}$ (Figure 5A). Offshore CPD isotherm trend ENE-WSW and E-W, whereas they are oriented NW-SE to NNW-SSE in the continental domain. The North Domain of BP (ND in Figs. 5 and 6), which is linked to the NAP basin, shows a more complex CPD relief, with values up to 39-km-deep in the zone domain (Figure 5A). To the east of this block CPD values in the coastal zone ranges from 27 to $23 \mathrm{~km}$. In the offshore zone of the North Domain (ND in Figs. 5 and 6), including the NAP domains and its limits with the Potiguar Basin, across the Touros Plateau, exhibit CPD values ranging from 29 to $21 \mathrm{~km}$. The main CPD isotherm in the offshore region is oriented ENE-WSW, E-W, and NNE-SSW (Figure 5A).

The GG and HF maps show that the continental region adjacent to the PEB exhibits values of 18 to $22{ }^{\circ} \mathrm{C} / \mathrm{km}$ and 38 to $50 \mathrm{~mW} / \mathrm{m} 2$, respectively (Figs. 6A and 6B). The offshore counterpart of the PEB presents values ranging from 19 to $26^{\circ} \mathrm{C} / \mathrm{km}$ and 44 to $60 \mathrm{~mW} / \mathrm{m} 2$ for the GG and HF, respectively. Higher-GG and -HF zones occur in the southeastern border of the PEP, with 23 to $28^{\circ} \mathrm{C} / \mathrm{km}$ and 47 to $63 \mathrm{~mW} / \mathrm{m} 2$, respectively (Figures 6A and 6B).

The continental region adjacent to the $\mathrm{PAB}$, in the $\mathrm{TZ}$ continental block, presents relatively homogeneous behavior, with values of 18 to $20^{\circ} \mathrm{C} / \mathrm{km}$, and 37 to $46 \mathrm{~mW} / \mathrm{m} 2$, for $\mathrm{GG}$ and $\mathrm{HF}$, respectively. The offshore region of the PAB presents values of GG ranging from 16 to $22^{\circ} \mathrm{C} / \mathrm{km}$ and values of $\mathrm{HF}$ ranging from 37 to $50 \mathrm{~mW} / \mathrm{m} 2$ (Figures 6A and 6B). 


\section{Jefferson Tavares Cruz Oliveira et al.}

The continental region adjacent to the NAP exhibits values of GG ranging from 16 to $23^{\circ} \mathrm{C} / \mathrm{km}$ and $\mathrm{HF}$ values ranging from 32 to $54 \mathrm{~mW} / \mathrm{m} 2$. The offshore region of NAP presents values of GG varying from 20 to $28^{\circ} \mathrm{C} / \mathrm{km}$ and values of $\mathrm{HF}$ varying from 45 to $65 \mathrm{~mW} / \mathrm{m} 2$ (Figures $6 \mathrm{~A}$ and $6 \mathrm{~B}$ ).

To evaluate the effect of prediction of thermal properties based on the estimated CPD, a set of 20 heat flow measurements collected in boreholes (Table 2) was used to make a comparison with values extracted for the same sites in the HF map (Figure 7). The data encompass 13 wells in the onshore region of NAP, Touros High, and the eastern limits of Potiguar Basin (ND); 1 well in the distal southeast border of the PEP; and 6 wells in the limits of the onshore Alagoas Basin (Figure 7). No measurement points are available for the onshore Pernambuco and Paraíba basins, neither for the offshore domains of the PAB and NAP. The comparative analysis of values shows that the average difference between the calculated HF values is approximately $20 \%$ lower than values measured in wells (Table 2). Differences can arise from different variables that influenced local measurements (depth of acquisition, geological factors, sampling techniques), being the thermal modeling results for the HF satisfactory for the regionalscale study.

\begin{tabular}{|c|c|c|c|c|c|}
\hline Well No. & Lat $S$ & Long E & $\mathrm{HF}\left(\mathrm{mW} / \mathrm{m}^{2}\right)$ & HF calc $\left(m W / m^{2}\right)$ & Difference \% \\
\hline 1 & $5^{\circ} 21^{\prime} 21^{\prime \prime}$ & $36^{\circ} 07^{\prime} 58^{\prime}$ & 73 & 68 & 9 \\
\hline 2 & $5^{\circ} 23^{\prime} 56^{\prime \prime}$ & $36^{\circ} 01^{\prime} 34^{\prime \prime}$ & 25 & 50 & -100 \\
\hline 3 & $5^{\circ} 26^{\prime} 02^{\prime \prime}$ & $36^{\circ} 01^{\prime} 42^{\prime \prime}$ & 63 & 52 & 17 \\
\hline 4 & $5^{\circ} 09^{\prime} 14^{\prime \prime}$ & $35^{\circ} 52^{\prime} 43^{\prime \prime}$ & 38 & 51 & -34 \\
\hline 5 & $5^{\circ} 13^{\prime} 20^{\prime \prime}$ & $35^{\circ} 48^{\prime} 58^{\prime \prime}$ & 77 & 48 & 38 \\
\hline 6 & $5^{\circ} 23^{\prime} 47^{\prime \prime}$ & $35^{\circ} 51^{\prime} 57^{\prime \prime}$ & 78 & 49 & 37 \\
\hline 7 & $5^{\circ} 31^{\prime} 09^{\prime \prime}$ & $35^{\circ} 49^{\prime} 49^{\prime \prime}$ & 55 & 48 & 13 \\
\hline 8 & $5^{\circ} 24^{\prime} 11^{\prime \prime}$ & $35^{\circ} 29^{\prime} 42^{\prime \prime}$ & 83 & 48 & 42 \\
\hline 9 & $5^{\circ} 37^{\prime} 55^{\prime \prime}$ & $35^{\circ} 35^{\prime} 20^{\prime \prime}$ & 71 & 49 & 31 \\
\hline 10 & $5^{\circ} 48^{\prime} 05^{\prime \prime}$ & $35^{\circ} 12^{\prime} 55^{\prime \prime}$ & 91 & 54 & 41 \\
\hline 11 & $5^{\circ} 21^{\prime} 07^{\prime \prime}$ & $35^{\circ} 21^{\prime} 18^{\prime \prime}$ & 46 & 53 & -15 \\
\hline 12 & $5^{\circ} 53^{\prime} 00^{\prime \prime}$ & $35^{\circ} 14^{\prime} 26^{\prime \prime}$ & 57 & 53 & 7 \\
\hline 13 & $6^{\circ} 00^{\prime} 09^{\prime \prime}$ & $35^{\circ} 09^{\prime} 34^{\prime \prime}$ & 91 & 51 & 44 \\
\hline 14 & $9^{\circ} 33^{\prime} 11^{\prime \prime}$ & $34^{\circ} 14^{\prime} 06^{\prime \prime}$ & 69 & 50 & 28 \\
\hline 15 & $9^{\circ} 37^{\prime} 08^{\prime \prime}$ & $35^{\circ} 43^{\prime} 59^{\prime \prime}$ & 51 & 49 & 4 \\
\hline 16 & $9^{\circ} 39^{\prime} 49^{\prime \prime}$ & $35^{\circ} 47^{\prime} 06^{\prime \prime}$ & 65 & 49 & 25 \\
\hline 17 & $9^{\circ} 52^{\prime} 57^{\prime \prime}$ & $35^{\circ} 59^{\prime} 03^{\prime \prime}$ & 53 & 49 & 8 \\
\hline 18 & $9^{\circ} 49^{\prime} 11^{\prime \prime}$ & $36^{\circ} 06^{\prime} 03^{\prime \prime}$ & 70 & 52 & 26 \\
\hline 19 & $9^{\circ} 47^{\prime} 04^{\prime \prime}$ & $36^{\circ} 06^{\prime} 59^{\prime \prime}$ & 65 & 52 & 20 \\
\hline 20 & $9^{\circ} 78^{\prime} 33^{\prime \prime}$ & $36^{\circ} 13^{\prime} 33^{\prime \prime}$ & 59 & 52 & 12 \\
\hline Average & & & 64 & 51 & 20 \\
\hline
\end{tabular}

Table 2. Comparison between heat flow (HF) measured in the boreholes (IHFC, 2018) and values extracted from the HF map calculated from CPD modeling.

\subsection{Seismic basement interpretation}

The depth to basement map of the offshore basins is shown in Figure 8B. The boundary between the Pernambuco and Alagoas basins is evidenced by the Maragogi-Barreiros High, an NW-SE-trending regional hinge. This high is linked with the Maracatu High, which forms the outer hinge of the PEP, trending NNE-SSW, and it is linked to the PESZ in the north. To the north of the PESZ, the continental platform of the PAB and NAP is dominated by a structural high trending N-S and NNW-SSE. The expression of this structural high that formed the continental platform is evidenced in the free-air anomaly map (Figure 3A) as a positive elongated anomaly extending from the southern limit of PEB to the northern limits of the Touros Plateau. 
The PEP framework is composed of deep grabens (Tamandaré, Guadalupe, and Itapuama), and outer highs formed over the continental thinned crust (Figure 7B). Two main outer highs dominate the central region of the plateau: the NW-SE-trending Itamaracá High, approximately $70 \mathrm{~km}$ long, which forms the plateau northern border, and the Gaibu High, a semicircular structure in the central region. The Xaréu Outer High, named in this work, trending to NNE-SSW, forms the boundary between the central region of the plateau and its most distal border. The Xaréu outer high also forms the first escarpment of the plateau (see seismic deep section crossing the plateau in Figure 10). The Itamaracá High is separated from the platform of the PEB by a structural strait named here as the Artax strait (Figure 8B). The seismic basement map allows us to define that the transect L2 (Figure 10) is positioned over a series of grabens, which top basement depth varies from 7 to $8 \mathrm{~km}$ below the sea level, and it also allowed to confirm that the first escarpment of the plateau is formed by a structural high that marks the limit of the transitional crust. This information was integrated in the transect L2 (Figure 10). The basement map also showed that the distal regions of these basins form a deep domain in contrast to the external hinge of the continental platform, which contributed to the changes in gravimetric anomalies observed along the crustal transition in the transects L1 and L2 (Figures 9 and 10).

\subsection{Integrated 2D deep seismic sections and geophysical transects}

We used information provided by interpretation of deep 2D seismic sections and data extracted from the calculated isostatic and thermal maps (Figures 3, 5, and 6) two integrate two geophysical transects (Figures 9 and 10). The transect L1 represents a 220-km-long dip section located in the distal region of the PAB (Figures 1, 3, and 8). In this area, the continental margin is very narrow, with a necking zone of approximately 40 to $60 \mathrm{~km}$ wide. Based on the interpretation of seismic data we proposed that a sector of hyper-thinned crust possibly formed an OCT zone of approximately 30 to $40 \mathrm{~km}$ wide (Figure 9). The shelf break is abrupt, with no proper slope, which caused the sedimentary deposits of the platform to fall over a very steep gradient to the distal basin (Figure 9). From the shelf break to the oceanic crust, the margin is approximately 80 to $100 \mathrm{~km}$ wide. The value of Free-air anomaly changes abruptly after the shelf break from - $40 \mathrm{mGal}$ to $-66 \mathrm{mGal}$ in about $28 \mathrm{~km}$, and then it increases to $-24 \mathrm{mGal}$ in the next $40 \mathrm{~km}$ across the beginning of the oceanic crust. After the beginning of the ocean crust, the Free-air anomaly shows an increase to $8 \mathrm{mGal}$, which is related to a seamount (Figure 9). The Free-air anomaly shows relative flat behavior related to the oceanic crust with values about $-23 \mathrm{mGal}$ (Figure 9). The Bouguer anomaly exhibit a constant increase in values from the shelf break, $50 \mathrm{mGal}$, to the next $100 \mathrm{~km}$ oceanward, to $265 \mathrm{mGal}$ across the Beginning of the oceanic crust. In the ocean domain, the Bouguer anomaly exhibits a gentle increase from 270 to $320 \mathrm{mGal}$ to the end of the transect (Figure 9).

The magnetic anomaly varies from $-22 \mathrm{nT}$ in the shelf break to $-35 \mathrm{nT}$ in the next $10 \mathrm{~km}$ oceanward, then it changes abruptly to $14 \mathrm{nT}$ in the next $12 \mathrm{~km}$, and then it varies abruptly again to $-4 \mathrm{nT}$ in the next $8 \mathrm{~km}$. The magnetic profile is limited to about $58 \mathrm{~km}$ due to the covering of the aeromagnetic survey in this region. The integration of data allowed us to corroborate the beginning of the oceanic crust at approximately 80 to $100 \mathrm{~km}$ from the shelf break (Figure 9). Along the necking zone, the isostatic Moho depth varies from $\sim 27 \mathrm{~km}$ ascending eastward to 20 $\mathrm{km}$ below the interpreted OCT zone and approximately $15 \mathrm{~km}$ below the oceanic crust (Figure 9). The CDP surface is approximately $2 \mathrm{~km}$ below the isostatic Moho in the shelf break (Figure 9), and it ascends gently to $26 \mathrm{~km}$ below the OCT zone (Figure 9). The CDP surface is approximately $8 \mathrm{~km}$ below the isostatic Moho along the interpreted OCT zone (Figure 9). The thickness of the continental crust in the narrow OCT zone is estimated at 10-12 km, and the thickness of the oceanic crust beyond the OCT zone is approximately $10 \mathrm{~km}$ (Figure 9).

The transect L2 represents a deep seismic section that crossed the distal region of the PEB (Figure 1) and extends from the shelf break region across the southern part of the PEP to the oceanic crustal domain, approximately 170 $\mathrm{km}$ long (Figure 10). The interpretation of seismic data shows that the continental margin in the PEP sector is wider than observed in the PAB (Figure 9). The integration of data suggests that the necking zone is 30 to $40 \mathrm{~km}$ wide, and the hyper-extended crust is approximately 80 to $90 \mathrm{~km}$ wide (Figure 10). A narrow region forms an outer high between the first inner escarpment and the escarpment that marks the border of the plateau and the beginning of the oceanic crust. We have interpreted this sector as an OCT zone, possibly a continuation of the OCT zone identified at the PAB, which is approximately 40 to $50 \mathrm{~km}$ wide in the PEP. The Free-air anomaly show values which vary abruptly from $36 \mathrm{mGal}$ in the shelf break to $-60 \mathrm{mGal}$ in the $20 \mathrm{~km}$ oceanward. That behavior is associated with the 


\section{Jefferson Tavares Cruz Oliveira et al.}

necking zone. The Free-air value then ascends to about -22 to $-25 \mathrm{mGal}$ in the next $60 \mathrm{~km}$ oceanward (Figure 10). This point marks the beginning of the sector interpreted as an OCT zone. In the OCT zone, the Free-air curve varies from $-30 \mathrm{mGal}$ to $-50 \mathrm{mGal}$ and again to $-30 \mathrm{mGal}$ in the next $60 \mathrm{~km}$ oceanward, forming a concave behavior. In the ocean domain, after the OCT zone, the Free-air shows values ranging from - $30 \mathrm{mGal}$ to $-12 \mathrm{mGal}$ (Figure 10). The Bouguer anomaly curve shows values from 100 to $110 \mathrm{mGal}$ in the shelf break, which ascends gently along the necking zone, $35 \mathrm{~km}$ oceanward, to values about $125 \mathrm{mGal}$. After the necking zone, the Bouguer anomaly ascends constantly and gently in the next $90 \mathrm{~km}$ oceanward to values about $280 \mathrm{mGal}$, to the point that marks the beginning of the ocean domain.

Bouguer anomaly values in the oceanic crust show a very gentle increase oceanward from $280 \mathrm{mGal}$ to $310 \mathrm{mGal}$ at the end of the transect (Figure 10). The magnetic anomaly curve varies from about -100 $\mathrm{nT}$ in the shelf break region to $-75 \mathrm{nT}$ in the next $20 \mathrm{~km}$ oceanward, which is related to the necking zone (Figure 10). From this point, the curves ascend from $-75 \mathrm{nT}$ to about $-2 \mathrm{nT}$ in the next $20 \mathrm{~km}$. The magnetic anomaly curve exhibit a sine shape with values varying from about $-1 \mathrm{nT}$ to $100 \mathrm{nT}$, and descending again to about -17 nT (Figure 10). This part of the magnetic anomaly curve is $40 \mathrm{~km}$ wide and corresponds to the center of the PEP. The next part of the curve presents a gentle variation with values ranging from $-15 \mathrm{nT}$ to $35 \mathrm{nT}$ in the next $20 \mathrm{~km}$ oceanward, which ends in the first escarpment of the plateau (Figure 10). Along the next $35 \mathrm{~km}$, the magnetic anomaly curve shows a sine shape with values varying from $-15 \mathrm{nT}$ to $70 \mathrm{nT}$. This part of the curve is related to the interpreted OCT zone, and at the beginning of the ocean crust, the magnetic anomaly varies from -20 nT to -94 nT (Figure 10).

Considering the estimated basement and the isostatic Moho depths, we infer that the crustal thickness in the central region of the Pernambuco Plateau is approximately $12 \mathrm{~km}$, and in the OCT zone, it is about 9 to $10 \mathrm{~km}$ (Figure 10). Interpretation o seismic and potential fields data allowed us to propose that the beginning of the oceanic crust domain is approximately 140 to $150 \mathrm{~km}$ from the shelf break (Figure 10). In this transect, the isostatic Moho is approximately $28 \mathrm{~km}$ deep after the shelf break at the beginning of the necking zone, and it ascends to approximately $22 \mathrm{~km}$ beneath the hyper-extended crust (Figure 10). The isostatic Moho ascends eastward to $18 \mathrm{~km}$ in the OCT zone and is approximately $16 \mathrm{~km}$ beneath the oceanic crust (Figure 10). The CPD isotherm is approximately $3 \mathrm{~km}$ above the isostatic Moho after the shelf break, in the necking zone, and it passes to below the isostatic Moho at the end of the necking zone. The CPD isotherm ascends gently below the Moho to approximately $22 \mathrm{~km}$ in the hyper-extended crust zone and $20 \mathrm{~km}$ in the OCT zone (Figure 10). The CPD isotherm is approximately 3 to $4 \mathrm{~km}$ below the isostatic Moho along the hyper-extended crust sector, and 4 to $5 \mathrm{~km}$ below the isostatic Moho along the OCT zone. The model also shows that the CPD isotherm is approximately $5 \mathrm{~km}$ below the oceanic crust eastward (Figure 10).

Comparison of depths of Moho boundary calculated by this research (isostatic Moho) and Moho depths estimated by the CRUST 1.0 project (earth's crust thickness) along the geophysical transects showed that both curves present similar behavior in the Paraíba Basin region (Transect L1) (Figure 9). The isostatic Moho is below the global Moho in the shelf break region, about $4 \mathrm{~km}$, and at the beginning of the oceanic crust, about $5 \mathrm{~km}$, and they present similar depths in the narrow margin and the oceanic crust (Figure 9). In the Pernambuco Basin (Transect L2) (Figure 10), the Global Moho and the isostatic Moho present similar behavior, but the first one is positioned above the isostatic Moho, and the difference between them varies from 3 to $6 \mathrm{~km}$ (Figure 10). The differences observed possibly are relative to the scale of the grids, the smoothing applied in global models, and differences in parameters adopted. The differences are within the predicted uncertainties estimated for the CRUST models [Tenzer et al., 2009].

Comparison of CPD calculated by the present research and data provided by the global CPD model calculated by Li et al. (2017) showed that in the Paraíba Basin (Transect L1) (Figure 9), the global CPD is near our CPD isotherm in the shelf break region, but it is below our CPD curve in the narrow hyper-thinned margin. The difference between the two curves in this region varies from 7 to 7,5 km (Figure 9). In the Pernambuco Basin region (Transect L2) (Figure 10), the curve extracted from the global CPD model (Li et al., 2017) is below our CPD curve, and they converge for a similar depth in the oceanic crust region (Figure 10). The difference between the two CPD curves in the hyper-extended margin region varies from 7 to $7,5 \mathrm{~km}$ (Figure 10). Differences observed between the two CPD models can be attributed to the different methodologies adopted, and to the scales of the grids created. Local complexities can influence CPD estimation, and we interpret that general behavior is correlated. 


\section{CPD Unveil NE Brazilian Margin Framework}

\section{Discussion}

Analysis of the seismic data (Figures 9 and 10), together with gravity maps (Figure 3), reveals that the northern part of the studied NE Brazilian marginal region is formed by a very narrow continental platform, with an abrupt shelf break and a narrow hyper-thinned continental crust, which encompasses the PAB and NAP basins (Figures 3, 5 , and 8). Otherwise, the southern sector presents a narrow continental platform and a wider hyper-extended continental crust section that formed the PEB and its plateau (Figures 8 and 10). The continental platform of these three basins is linked and constitutes a regional basement high that dominates the margin (Figures 3A and 8). The framework of PEP exhibits deep grabens and outer highs that formed a complex morphology, including a $\sim 50 \mathrm{~km}$ wide transitional crust zone sector (Figure 9). The major grabens within the PEP reach 8 to $9 \mathrm{~km}$ below the sea level. The origin and crustal nature of the large Itamaracá and Gaibu outer highs (Figures 8 and 10) are still unknown, but they are linked to magmatic activities [Buarque et al., 2016] and crustal heterogeneities within the hyper-extended crust [Magalhães et al., 2014]. Our interpretation regarding the occurrence of a short marginal extent, characterized by a hyper-thinned crust and the lack of structures like seaward-dipping reflectors corroborate previous studies that have suggested that the central segment of the South Atlantic Ocean shows affinity to the magma-poor model [Reston et al., 2009; Haupert et al., 2016].

Comparison of CPD values obtained in this study for the adjacent BP basemen of the marginal basins and Curie isotherm estimated by Correa et al. [2016] for the BP by performing spectral analysis of airborne magnetic data show good correlation. They found that calculated CDP values in the BP continental shield vary from 18 to $59 \mathrm{~km}$. They also produced a heat flow map for the BP, whose values range between 25 and $259 \mathrm{~mW} / \mathrm{m}^{2}$, with an average of $67 \mathrm{~mW} / \mathrm{m}^{2}$. According to these authors, however, higher HF values were likely caused by shallow hydrothermal fluids.

A few investigations have been published on crust thermal properties of the South American platform, focusing on southeastern continental margins [Gomes and Hamza, 2005; Cardozo and Hamza, 2014] and cratonic regions [Blum, 1996; Hurter and Pollack, 1996; Guimarães et al., 2013; Correa et al., 2016]. A study of the thermal gradient in the onshore region of the Potiguar Basin, based on 164 stratigraphic wells, showed geothermal gradients ranging from 24 to $74^{\circ} \mathrm{C} / \mathrm{km}$, with a mean value of $37^{\circ} \mathrm{C} / \mathrm{km}$ [Souto Filho, 1984]. According to the latter study, the values calculated for the eastern border of the Potiguar Basin vary from 26 to $46^{\circ} \mathrm{C} / \mathrm{km}$, which is consistent with our results in the northern portion of the ND (continental region between the Touros High and Potiguar Basin) (Figures 6B and 6C). Hamza et al. [2018] elaborated the GG and HF maps for the passive Brazilian margin and its adjacent basement using bottom-hole temperature (BHT) data and sea-bottom temperature measurements, and Comparison of their results show that the GG and HF distributions and intensities are quite similar to the values found in the present study for the eastern margin of the BP (Figure 6).

The most important finding of the CPD estimation in this study is the strong control of the BP sub-domains (SD, TZ, and ND) on the thermal characteristics of the continental platform and marginal basins. Analysis of the thermal maps (CPD, GG, and HF) reveals that the basement inheritance controlled the evolution of the marginal basins in the studied area. The regional distribution of the CPD values of the three blocks that form the BP show correlation with the CPD values in the three marginal basins. The CPD isotherms in the SD are bounded by the PESZ to the north, and they show intermediate-depth values, between 32 and $19 \mathrm{~km}$, with a shallower zone in the southeast border of the Pernambuco Plateau (Figure 5A). An NNE-SSW-trending elliptical CPD low, approximately $50 \mathrm{~km}$ long, with depth values varying from 25 to $21 \mathrm{~km}$, is located southwest of Recife in the coastal zone. This shallow CPD zone is spatially associated with the Albian magmatic pulse in the coastal zone of the PEB. The TZ exhibits deeper CPD values than the ND and SD, ranging from 39 to $28 \mathrm{~km}$ in the adjacent continental region, continental platform, and distal basin (Figure 5A). It is remarkable how the ENE-WSW-trending CPD distribution is bounded by the PASZ within the TZ to the north. The ND presents a more complex distribution of CPD anomalies, with deeper values in the adjacent continental region, ranging from 39 to $27 \mathrm{~km}$, and shallower values, ranging from 27 to $21 \mathrm{~km}$, in the basin border of the continental platform and towards the marginal basin over the Touros Plateau (Figure 5A). Therefore, the regional analysis of GG and HF maps show that the PEB and related SD present more intense geothermal flux compared to the PAB and the related TZ (Figures 6A and 6B). The ND presents less intense thermal flux in the adjacent continental region but higher values in the marginal basin, including the NAP and the Touros Plateau (Figure 6C). This warmer condition of the offshore region of the ND could be linked to the influence of a thermal mantle anomaly located beneath the Eastern Equatorial Brazilian margin that generated a series of alkaline magmatic pulses (volcanic plugs and flows) during the Cenozoic [Knesel et al., 2010]. This region 


\section{Jefferson Tavares Cruz Oliveira et al.}

was also affected by tholeiitic magmatism during the rifting process, possibly associated with the Santa Helena hotspot (130 to 120 Myr) [Sial et al., 1981; Archanjo and Araújo, 2002]. Estimated CPD isotherm showed that the southern block of BP seems to represent a warmer and younger crustal block to the TZ and ND, which impacted the evolution during the margin formation. The lithological composition certainly plays an important hole in the thermal properties of the crust. The BP basement mainly comprises Paleoproterozoic orthogneisses dating from 2.2 to $2.0 \mathrm{Ga}$, with exposures of Archean and Early Paleoproterozoic crust occurring in the ND and TZ [Neves et al., 2012]. The ND consists of metasedimentary and metavolcanic rocks dominated by schists and metarhyolites. The TZ domain is composed by a series of terrains, which contain greenschist metapelites, metasedimentary and bimodal metavolcanics. The SD is divided in two sectors: northern, which contains high-grade, migmatitic orthogneisses and metasedimentary rocks (over which the PEB was formed), and southern, with metasedimentary units. Unknown deep features of the continental blocks could influence their thermal properties. Further analyses are necessary to address the influence of the thickness and physical nature of each BP sub-domain on their thermal properties.

The study of Lima et al. [2015], based on a $900 \mathrm{~km}$ seismic refraction/wide-angle reflection profile across the Borborema shield, showed that the BP present a smooth Moho topography and that the velocities in the lower and upper crust of the TZ are slightly lower than what was found for the SD and the ND. This work proposed that there is no deep root, or crustal underplating, associated with the higher topography of TZ, whose underlying crust is thicker than the crust beneath SD. This research also showed that the Moho depth is around 31.5 in the ND, 32 to $33 \mathrm{~km}$ in the TZ, and it is around $35 \mathrm{~km}$ in the SD. There is a good correlation between the information on the relative thickness of the BP domains and the thermal characteristics we found for each domain in our CPD investigation: the intermediate-thickness SD (intermediate CPD, GG, and HF), the thicker TZ (deeper CPD), and the thinner ND (shallower CPD in the marginal basins and adjacent basement).

Analysis of the relationship between the calculated isostatic Moho depths and the CPD isotherm surface (Figures 9,10 and 11) shows that the CPD is overall above the isostatic Moho in the onshore and proximal continental margin, except for a small area in the TZ. In the onshore region, the vertical difference between the Curie isotherm and Moho depths vary from 2 to $5.5 \mathrm{~km}$ in the SD, from 2 to $11 \mathrm{~km}$ in the TZ, and 5.5 to $9 \mathrm{~km}$ in the ND (Figures 9, 10 and 11). However, in two regions of the continental basement, the CPD isotherm is deeper than the isostatic Moho: the northern portion of the TZ, near the coastal zone, and in the southern portion of the ND (Figure 11). The deepening of the CDP in the continental region forms a ENE-WSW-trending valley, aligned with the PASZ (Figure 11). The distance between the coast line and the point where the CPD isotherm passes below the isostatic Moho surface varies from $72 \mathrm{~km}$ in the southern area of the PEB to approximately $118 \mathrm{~km}$ in the north-central region of the PEB. In these areas the coverage of both data are similar which support the interpretation of their relative position (Figure 11C).

Our estimated depths of the Moho boundary show similar behavior compared to the global Moho relief estimated by the Crust 1.0 project (Figures 9 and 10). Our isostatic model showed deeper values for the Moho, but they are within the variation considered for this global grid. The values we have estimated for the CPD show differences compared to depths extracted from the global CPD model created by Li et al. [2017] over the L1 and L2 transects (Figures 9 and 10). However, the global CPD was below both the Moho relief of the Crust 1.0 model and the isostatic model (Figures 9 and 10). This comparison showed that despite differences observed in the estimated depths of both boundaries, the aspects provided by the study of their relationship are useful to the understanding of the margin evolution.

The positioning of the CPD below the Moho has important implications for the geotectonic history and the present framework of the studied margin. Cold magnetic mantle $\left(<600^{\circ} \mathrm{C}\right)$ can exist below Archean and Proterozoic shields, subduction zones, and old oceanic plates [Ferré et al., 2014; Ismaie et al., 2019]. In some geological settings, the cold and magnetic uppermost mantle can exhibit a thickness of tens of kilometers [Ferré et al., 2013]. In this sense, the Curie point will lie below the crust-mantle boundary [Thébault et al., 2010; Correa et al., 2016]. No direct correlation exists between the depth of the isostatic Moho and the depth of the Curie isotherm. The Moho represents a seismic discontinuity influenced by many factors, such as over- and underplating, the mineralogy, and the temperature. The depth of this boundary can change throughout time over cratonic regions and is transitional in noncratonic regions [O’Reilly and Griffin, 2013; Wang et al., 2013; Thybo and Artemieva, 2013]. The Curie isotherm depends on the mineralogical composition of the crust and upper mantle, the crustal thickness, the tectonic environment, and other physical parameters, such as pressure and temperature [Wasilewsk and Mayhew, 1992; Tanaka et al., 1999; Rajaram et al., 2009; Thébault et al., 2010; Ferré et al., 2014]. Idárraga-García and Vargas [2018] 
studied the behavior of CPD on the South American continent, based on satellite data, and verified that the Curie surface occurs below the Moho in the stable central and north sectors of the Brazilian shield as well in some parts of the Andean Cordillera. One cause associated with this process is the serpentinization of the mantle beneath cratonic regions, subduction zones and oceanic plates [Manea and Manea, 2010; Li et al, 2013, 2016; Ravat et al., 2011; Guillot et al., 2015; Wang and Li, 2015; Andrés et al., 2017]. Indeed, Correa et al. [2016] found that the Curie isotherm is deeper than the Moho in some regions of the BP, and they attributed this phenomenon to serpentinization of mantle below the uplifted BP.

The studied margin was subject to the lowest spreading rates during the Central Atlantic formation [Brune et al., $2014 ; 2016]$. As a tectonic result, an asymmetric conjugate margin developed, where the northeast Brazilian margin corresponded to the narrow side of a hyper-extended plate. The hyper-extended model proposed for this segment of the Brazilian margin suggested that the continental margin could present an extension of 60 to $80 \mathrm{~km}$ wide [Brune et al., 2014], which is consistent with what we found for the PAB and NAP. However, the additional extension observed in the PEP, more than $150 \mathrm{~km}$, could be associated with the oblique rifting that affected this region. Serpentinization is a process that can occur with the formation of hyper-extended magma-poor margins [Lundin et al., 2011; Sutra and Manatschal, 2012; Pérez-Gussinyé, 2013; Guillot et al., 2015; Ros et al., 2017], with the development of serpentinized mantle bodies below the necking zone across the OCT zone, due to the mantle exhumation, and consequent ocean water and lithospheric mantle interaction. The geophysical evidence gathered here corroborates the present hypothesis, as the region presents the expected characteristic of a hyper-extended margin, especially a narrow OCT zone where the Curie isotherm is below the isostatic Moho. This OCT zone is 20 to $30 \mathrm{~km}$ wide in the Paraíba and Natal platform regions (Figure 9) and approximately 40 to $50 \mathrm{~km}$ wide in the Pernambuco Plateau region (Figure 10).

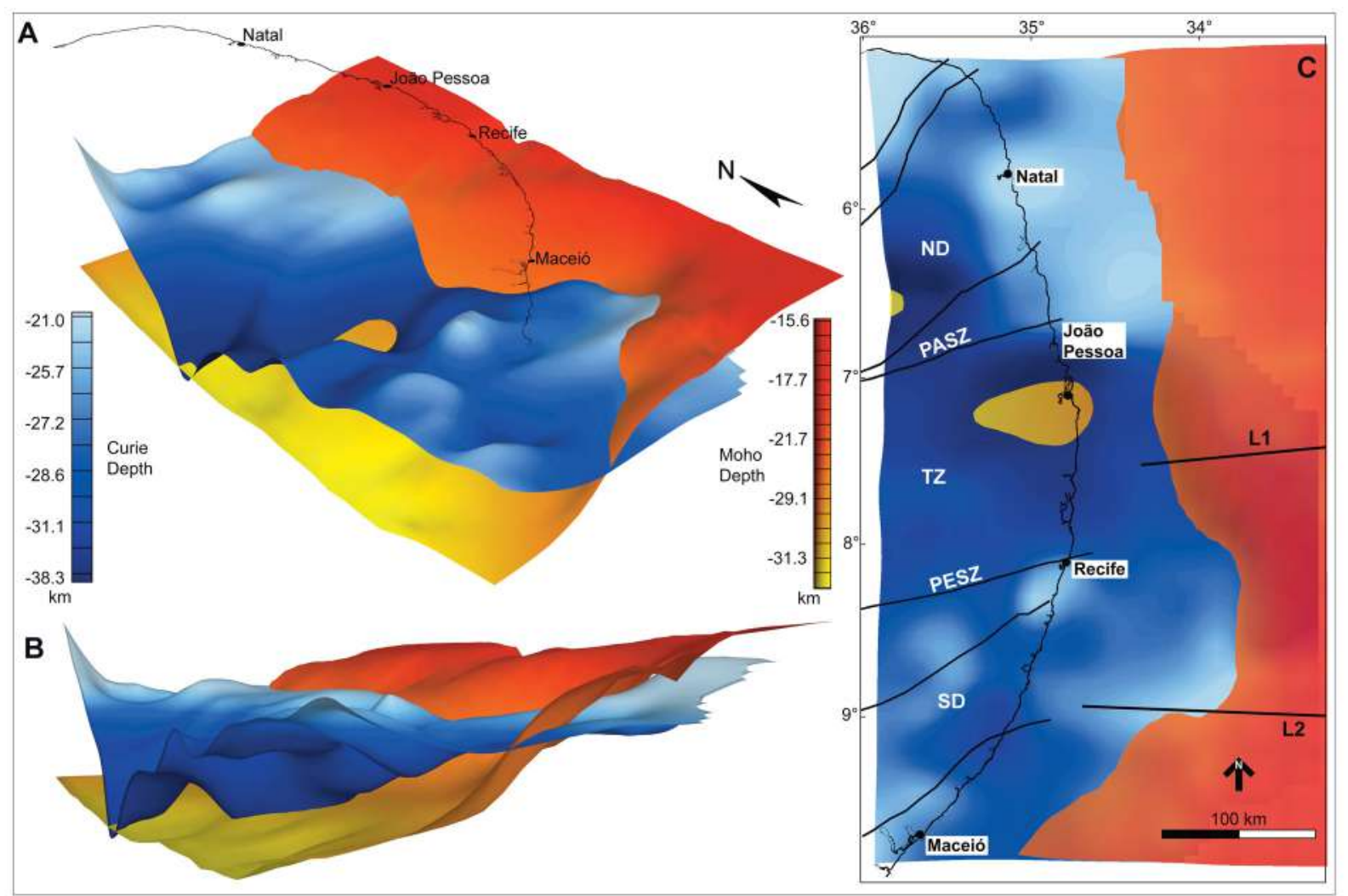

Figure 11. 3D visualization of the relationship between the CPD isotherm and the isostatic Moho surface in the studied region. Thin black line: coastline for reference. A and B) 3D view of the surfaces (V.E. = 2.5). C) Plan view of the maps showing the position where the Curie isotherm passes under the isostatic Moho boundary. 


\section{Jefferson Tavares Cruz Oliveira et al.}

Further studies like seismic-derived velocity models are necessary to consolidate the proposed model and the nature of the OCT zone. However, the estimation of CPD is useful to the study of marginal regions where geophysical data is scarce as is the case for the studied region. The inference that the CPD is below the Moho in a scenario of hyper-thinned crust corroborates the hyper-extended model for this margin, and it also helps to suggests that this margin possibly was affected by serpentinization associated with the formation of a narrow OCT zone [Li et al., 2010; Salem et al., 2014].

\section{Conclusions}

CPD estimation together with the estimation of isostatic Moho depths and interpretation of deep seismic sections provided an important overview of the lithospheric characteristics of the eastern continental margin of northeast Brazil. The region comprises a narrow continental margin formed by a hyper-extended crust that is 150 $\mathrm{km}$ wide in the PEB, $80 \mathrm{~km}$ wide in the PAB, and approximately $60 \mathrm{~km}$ wide in the NAP. The PEP, the larger sector of the studied area, presents deep grabens with basement depths varying from 8 to $9 \mathrm{~km}$ below the sea level. Analysis of deep seismic sections allowed us to suggest that the margin presents an ocean-continent transitional crust (OCT) zone that is approximately $40-50 \mathrm{~km}$ wide in the PEB Basin and 30 to $40 \mathrm{~km}$ wide in the PAB and NAP. The OCT zone is characterized by a thinner crust sector, which was possibly affected by serpentinization. The OCT was also interpreted based on the analysis of gravimetric data.

Analysis of CPD, as well the GG and HF maps, shows that the thermal properties of marginal basins were strongly controlled by the nature and structure of continental blocks that formed the BP, which also controlled the tectonic evolution of each basin. The PEB and its adjacent basement exhibit intermediate to shallow CPD values and higher values of GG and HF, which are bounded by the PESZ. The PAB and its adjacent basement show deeper CPD values, as well as lower GG and HF values. The regional trend of the PAB is bounded by the PASZ. The NAP is characterized by shallower CPD values in the adjacent border and continental platform of this basin. The continental basement of the NAP presents deeper CPD values, as well as lower GG and HF values. These differences possibly are related to the crustal thickness and lithological nature of each continental block.

Analysis of the relationship between the CPD isotherm and isostatic Moho suggests that the CPD can be below or near the Moho boundary in the marginal region. This aspect could be caused by the serpentinization process that occurs in hyper-extended continental margins with the consequent magnetization of the lithospheric mantle. However, further studies are necessary to prove this interpretation.

Acknowledgements. We wish to thank the Sinochem Petróleo Brasil Ltda., which funded this research through the cooperation agreement FADE/UFPE/Sinochem - "seasound" project. We also thank to the National Agency of Petroleum, Natural Gas and Biofuels (ANP), for providing the data used in this research. And Brazilian Navy for providing additional seismic data from the LEPLAC Program.

\section{References}

Aboud, E., A.M. Alotaibi and R. Saud (2016). Relationship between Curie isotherm surface and Moho discontinuity in the Arabian shield, Saudi Arabia, J. Asian Earth Sci., 128, 42-53.

Abraham, E.M., K.M. Lawal, A.C. Ekwe, O. Alile, K.A. Murana and A.A. Lawal (2014a). Spectral analysis of aeromagnetic data for geothermal energy investigation of Ikogosi Warm Spring - Ekiti State, Southewestern Nigeria, Geothermal Energy, 2, 6, 1-21.

Abraham, E.M., K.M. Lawal, A.C. Ekwe, O. Alile, K.A. Murana and A.A. Lawal (2014b). Reply to discussion on “Spectral analysis of aeromagnetic data for geothermal energy investigation of Ikogosi Warm Spring - Ekiti State, Southewestern Nigeria”, Geothermal Energy, 2, 18, 1-5.

Almeida, F.F.M., Y. Hasui, B.B. Brito Neves and R.A. Fuck (1981). Brazilian structural provinces: an introduction, Earth-Sci. Rev, 17, 1-2, 1-29.

Almeida, C.B., L.R. Cruz, E.F. Jardim de Sá, P.M.P. Vasconcelos and W.E. Medeiros (2005). Tectônica e relações 


\section{CPD Unveil NE Brazilian Margin Framework}

estratigráficas na sub-bacia de Pernambuco, NE do Brasil: contribuição ao conhecimento do rifte Sul-Atlântico, Boletim de Geociências da Petrobras, 13, 2, 167-180.

Andrés, J., I. Marzán, P. Ayarza, D. Martí, Palomeras, M. Torné, S. Campbell and R. Carbonell (2017). Curie Point Depth of the Iberian Peninsula and Surrounding Margins. A Thermal and Tectonic Perspective of its Evolution, J. Geophys. Res., 123, 3, 2049-2068.

Archanjo, C.J. and M.G.S. Araújo (2002). Fabric of the Rio Ceará-Mirim mafic dike swarm (northeastern Brazil) determined by anisotropy of magnetic susceptibility and image analysis, J. Geophys. Res., 107, 1-13.

Araujo, C.E.G., R.F. Weinberg and U.G. Cordani (2013). Extruding the Borborema Province (NE-Brazil): a two stage Neoproterozoic collision process, Terra Nova, 26, 2, 157-168.

Aslanian, D., M. Moulin, J. Olivet, P. Unternehr, L. Matias, F. Bache, M. Rabineau, H. Nouzé, F. Klingelheofer, I. Contrucci and C. Labails (2009). Brazilian and African passive margins of the Central Segment of the South Atlantic Ocean: Kinematic constraints, Tectonophysics, 468, 1-4, 98-112.

Ates, A., F. Bilim and A. Buyuksarac (2005). Curie Point Depth Investigation of Central Anatolia, Turkey, Pure appl. Geophys., 162, 357-371.Aydemir, A., F. Bilim, S. Kosaroglu and A. Buyuksarac (2019). Thermal structure of the Cappadocia region, Turkey: a review with geophysical methods, Mediterranean Geoscience Reviews, 1, 243-254.

Balmino, G., N. Vales, S. Bonvalot and A Briais (2012). Spherical harmonic modelling to ultra-high degree of Bouguer and isostatic anomalies, J. Geodesy, 86, 499-520.

Barbosa, J.A. and M.F. Lima Filho (2006). Aspectos estruturais e estratigráficos da faixa costeira Recife-Natal: observações em dados de poços, Boletim de Geociências da Petrobras, 14, 2, 287-306.

Barbosa, J.A., V.H. Neumann, M.F. Lima Filho, E.M. Souza and M.A. Moraes (2007). Estratigrafia da faixa costeira Recife-Natal (Bacia da Paraíba e Plataforma de Natal), NE Brasil, Estudos Geológicos, 17, 2, 3-30.

Barbosa, J.A., M.F.B. Maia, M.F. Lima Filho, J.R.G. Magalhães and O.J. Correia Filho (2014). Seismic stratigraphy of the onshore portion of Pernambuco Basin: evidence of break up during Middle Albian for the South Atlantic Rift in Northeast Brazil, in AAPG Annual Exhibition and Convention, Houston, Article \#90189, 1-10.

Beardsmore, G.R and J.P. Cull (2001). Crustal Heat Flow A Guide to Measurement and Modelling, Cambridge university press, Cambridge, 1-324.

Bektas, O., D. Ravat, A. Buyuksarac, F. Bilim and A. Ates (2007). Regional Geothermal Characterization of East Anatolia from Aeromagnetic, Heat Flow and Gravity Data, Pure. Appl. Geophys., 164, 975-998.

Bektas O. (2013). Thermal structure of the crust in Inner East Anatolia from aeromagnetic and gravity data, Phys. Earth. Planet. Inter., 221, 27-37.

Bezerra, F.H.R., D.F. Rossetti, R.G. Oliveira, W.E. Medeiros, B.B. Britos Neves, F. Balsamo, F.C.C. Nogueira, E.L. Dantas, C. Andrades Filho and A.M. Góes (2014). Neotectonic reactivation of shear zones and implications for faulting style and geometry in the continental margin of NE Brazil, Tectonophysics, 614, 78-90.

Bhattacharyya, B.K. and L.W. Morley (1965). The delineation of deep crustal magnetic bodies from total field aeromagnetic anomalies, J. Geomagn. Geoelectr., 17, 3-4, 237-252.

Bhattacharyya, B.K. and L. Leu (1975a). Spectral analysis of gravity and magnetic anomalies due to two-dimensional structures, Geophysics, 40, 6, 993-1013.

Bhattacharyya, B.K. and L. Leu (1975b). Analysis of magnetic anomalies over Yellowstone national park: mapping and curie point isothermal surface for geothermal reconnaissance, J. Geophysics, 80, 32, 4461-4465.

Bhattacharyya, B.K. and L. Leu (1977). Spectral analysis of gravity and magnetic anomalies due to rectangular prismatic bodies, Geophysics, 42, 1, 41-50.

Blaich, O.A., F. Tsikalas and J.I. Faleide (2008). Northeastern Brazilian margin: Regional tectonic evolution based on integrated analysis of seismic reflection and potential field data and modelling, Tectonophysics, 458, 1-4, 51-67.

Blaich, OA., J.I. Faleide and F. Tsikalas (2011). Crustal breakup and continent-ocean transition at the South Atlantic conjugate margins, J. Geophys Res., 116, B-1, 1-38.

Blakely, R.J. (1995). Potential Theory in Gravity and Magnetic Applications, Cambridge University Press, Cambridge, $1-464$

Blakely, R.J., T.M. Brocher and R. E. Wells (2005). Subduction-zone magnetic anomalies and implications for hydrated forearc mantle, Geology, 33, 6, 445-448.

Blum, M.L.B. and A.C.B. Pires (1996). Superfície Curie da região central de goiás. Revista Brasileira de Geociências, 26, 3, 197-208.

Bouligand, C., J.M.G. Glen and R.J. Blakely (2009). Mapping Curie temperature depth in the western United States 


\section{Jefferson Tavares Cruz Oliveira et al.}

with a fractal model for crustal magnetization, J. Geophys. Res., 114, B11, 1-25.

Brito, Neves. B.B., W.R. Van Schmus and A. Fetter (2002). North-western Africa-North-eastern Brazil. Major tectonic links and correlation problems, J. African Earth Sci., 34, 3-4, 275-278.

Brune, S., C. Heine, M. Pérez-Gussinyé and S.V. Sobolove (2014). Rift migration explains continental margin asymmetry and crustal hyper-extension, Nat. Commun, 5, 4014, 1-6.

Brune, S., Simon, S.E. Williams, N.P. Butterworth and R.D. Müller (2016). Abrupt plate accelerations shape rifted continental margins, Nature, 536, 201-2014.

Buarque, B.V., J.A. Barbosa, J.R.G. Magalhães, J.T.C. Oliveira and O.J. Correia Filho (2016). Post-rift volcanic structures of the Pernambuco Plateau, Northeastern Brazil, J. S. Am. Earth Sci., 70, 251-267.

Buarque, B.V., J.A. Barbosa, J.T.C. Oliveira, J.R.G. Magalhães, and O.J. Correia Filho (2017). Carbonate Buildups in the Pernambuco Basin, NE Brazil, An. Acad. Bras. Cienc., 89, 2, 841-857.

Chang, H.K., R.O. Kowsmann, A.M.F. Figueiredo and A.A. Bender (1992). Tectonics and Stratigraphy of the East Brazil Rift system: an overvie, Tectonophysics, 213, 1-2, 97-138.

Chiozzi, P., J. Matsushima, Y. Okubo, V. Pasquale and M. Verdoya (2005). Curie-point depth from spectral analysis of magnetic data in central-southern Europe, Phys. Earth Planet. Inter., 152, 4, 267-276.

Chopping, R. and B.L.N. Kennet (2015). Maximum depth of magnetization of Australia, its uncertainty, and implications for Curie depth, Geo. Res. J., 7, 70-77.

Correa, R.T., R.M. Vidotti and E. Oksum (2016). Curie surface of Borborema Province, Brazil, Tectonophysics, 679, 73-87.

De Castro, D.L., F.H.R. Bezerra, M.O.L. Sousa and R.A. Fuck (2012). Influence of Neoproterozoic tectonic fabric on the origin of the Potiguar Basin, northeastern Brazil and its links with West Africa based on Gravity and Magnetic Data, J. Geodyn., 54, 29-42.

Dolmaz, M.N., T. Ustaömer, Z.M. Hisarli and N. Orbay (2005). Curie Pont Depth variations to infer thermal structure of the crust at the African-Eurasian convergence zone, SW turkey, Earth, Planets and Space, 57, 373-383.

Eppelbaum, L., I. Kutasov and A. Pilchin (2014). Thermal properties of rocks and density of fluids, Applied Geothermics, Springer, Berlin, 99-149.

Fainstein, R. and J.D. Milliman (1979). Structure and origin of three continental-margin plateaus, Northeastern Brazil, AAPG Bull., 63, 2, 218-238.

Ferreira, J.M., F.H.R. Bezerra, M.O.L. Sousa, A.F. Nascimento, J.M. De Sá and G. S França (2008). The role of Precambrian mylonitic belts and present-day stress field in the coseismic reactivation of the Pernambuco lineament, Brazil. Tectonophysics, 456, 3-4, 111-126.

Ferré, E.C., S.A. Friedman, F. Martín-Hernández, J.M. Feinberg, J.A. Conder and D.A. Ionov (2013). The magnetism of mantle xenoliths and potential implications for sub-Moho magnetic source, Geophys. Res. Lett., 40, 1, 105-110.

Ferré, E.C., S.A. Friedman, F. Martín-Hernández, J.M. Feinberg, J.L. Till, D. A. Ionov and J. A. Conder (2014). Eight good reasons why the uppermost mantle could be magnetic, Tectonophysics, 624-625, 3-14.

Franke, D. (2013). Rifting, lithosphere breakup and volcanism: Comparison of magma-poor and volcanic rifted margins, Mar. Petrol. Geol., 43, 63-87.

Fullea, J., M. Fernandez and H. Zeyen (2008). FA2BOUG - A FORTRAN 90 code to compute Bouguer gravity anomalies from gridded free-air anomalies: Application to the Atlantic-Mediterranean transition zone, Comput. Geosci., $34,12,1665-1681$.

Gaudreau, É., P. Audet and D.A. Schneider (2019). Mapping Curie Depth Across Western Canada From a Wavelet Analysis of Magnetic Anomaly Data, J. Geophys. Res., 124, 5, 4365-4385.

Gillard, M., D. Sauter, J. Tugend, S., Tomasi, M. Epin and G. Manatschal (2017). Birth of an oceanic spreading center at a magma-poor rift system, Sci. Rep., 7, 15072, 1-6.

Gomes, P.O., B.S. Gomes, J.J. C. Palma, K. Jinno and J.M. De Souza (2000). Ocean-continent transition and tectonic framework of the oceanic crust at the continental margin of Northeast Brazil: results of LEPLAC Project, Geophys. Monogr. Ser., 15, 261-291.

Gomes, A.J.L. and V.M. Hamza (2005). Geothermal gradiente and heat flow in the state of Rio de Janeiro, Revista Brasilieira de Geofísica, 23, 4, 325-347.

Guillot, S., S. Schwartz, B. Reynard, P. Agard and C. Prigent (2015). Tectonic significance of serpentinites, Tectonophysics, 646, 1-19.

Guimarães, S.N.P., V.M. Hamza and D. Ravat (2013). Curie depths using combined analysis of centroid and matched filtering methods in inferring thermomagnetic characteristics of central Brazil, SEG Global Meeting Rio de 


\section{CPD Unveil NE Brazilian Margin Framework}

Janeiro, 1853-1858.

Guimarães, S.N.P., D. Ravat and V.M. Hamza (2014). Combined use of the centroid and matched filtering spectral magnetic methods in determining thermomagnetic characteristics of the crust in the structural provinces of Central Brazil, Tectonophysics, 624-625, 87-99.

Hamza, V.M., F.P. Vieira and R.T.A. Silva (2018). Anomalous heat flow belt along the continental margin of Brazil, Int. J. Earth. Sci, 107, 1, 19-33.

Haupert, I., G. Manatschal, A. Decarlis and P. Unternehr (2016). Upper-plate magma-poor rifted margins: Stratigraphic architecture and structural evolution, Mar. Petrol. Geol., 69, 241-261.

Heiskanen, W.A. and H. Moritz (1967). Physical Geodesy, Bull. Geodesique, 86, 491-492.

Hsieh, H., Chen C., Lin P. and H. Yen (2014). Curie point depth from spectral analysis of magnetic data in Taiwan, J. Asian Earth Sci., 90, 26-33.

Hurter, S.J. and H.N. Pollack (1996). Terrestrial heat flow in the Paraná Basin, southern Brazil, J. Geophys. Res., 101, B4, 8659-8671.

Idárraga-García, J. and C.A. Vargas (2018). Depth to the bottom of magnetic layer in South America and its relationship to curie isotherm, Moho depth and seismicity behavior, Geod. Geodyn., 9, 1, 93-107.

Mohammad, I., K.S. Krishna, K. Srinivas, J. Mishra and D. Saha (2019). Crustal architecture and Moho topography beneath the eastern Indian and Bangladesh margins - new insights on rift evolution and the continent-ocean boundary, J. Geol. Soc., 176, 3, 553-573.

Jaupart, C. and J.C. Mareschal (2007). Heat flow and thermal structure of the lithosphere, in A.B. Watts (Editor), Treatise on Geophysics, 6: The Lithosphere, 2nd Edition, Elsevier, Amsterdam, 217-251.

Johnson, A.C., A. Sarris, and M.E. Amza-Prein (1999). New interactive fft-based grid suturing technique applied to ground geophysical surveys in Greece, in Second Balkan Geophysical Congress and Exhibition, Istanbul, 90-91.

Kappelmeyer, O. and R. Haenel (1974). Geothermics with special reference to application, Gebrueder Borntrargen, Berlin, 1-235.

Knesel, K.M., A.S. Souza, P.M. Vasconcelos, B.E. Cohen and F.V. Silveira (2010). Young volcanism in the Borborema Province, NE Brazil, shows no evidence for a trace of the Fernando de Noronha plume on the continent, Earth Planet. Sci. Lett., 302, 1-2, 38-50.

Leseane, K., E.A. Atekawa, K.L. Mickusm, M.G. Abdelsalam, E.M. Shemang and E.A. Atekawa (2015). Thermal perturbations beneath the incipient Okavango rift Zone, Northewest Botswana, J. Geophys. Res., 120, 2, 12101228.

Li, C., X. Shi, Z. Zhou, J. Li, J. Geng and B. Chen (2010). Depths to the magnetic layer bottom in the South China Sea area and their tectonic implications, Geophys. J. Int., 182, 1229-1247.

Li, C., J. Wang, J. Lin and T. Wang (2013). Thermal evolution of the North Atlantic lithosphere: New constraints from magnetic anomaly inversion with a fractal magnetization model, Geochem. Geophys. Geosyst., 14, 12, 50785105.

Li, C., L. Yu and J. Wang (2017). A global reference model of Curie-point depths based on EMAG2, Sci. Rep., 7, 45129.

Li, C. and J. Wang (2016). Variations in Moho and Curie depths and heat flow in Eastern and Southeastern Asia, Mar. Geophys. Res., 37, 1-20.

Lima, M.V.A.G., J. Berrocal, J.E.P. Soares and R.A. Fuck (2015). Deep seismic refraction experiment in northeast Brazil: New constraints for Borborema province evolution, J. Soc. Am. Earth Sci., 58, 335-349.

Lima, Filho M.F. (1998). Análise Estrutural e Estratigráfica da Bacia Pernambuco. Ph.D. Thesis, Universidade Federal de Pernambuco, Brazil.

Lima, Filho M.F. and J.A. Barbosa (2010). The peculiar tectono-stratigraphic evolution of the eastern margin of Northeast Brazil, and its African counterpart, in 2nd Central and North Atlantic Conjugate Margins Conference, Lisbon, 8, 304-308.

Long, L.E., A.N. Sial, H. Nekvasil and G.S. Borba (1986). Origin of Granite at Cabo de Santo Agostinho, Northeast Brazil, Contrib. Mineral Petr., 92, 341-350.

Lundin, E.R. and A. Doré G (2011). Hyperextension, serpentinization, and weakening: A new paradigm for rifted margin compressional deformation, Geology, 39, 4, 347-350.

Mabesoone, J.M. and M.M. Alheiros (1993). Evolution of the Pernambuco-Paraíba-Rio Grande do Norte Basin and the problem of the South Atlantic connection, Geologie en Mijnbouw, 71, 351-362.

Magalhães, J.R.G., J.T.C. Oliveira, J.A. Barbosa and M.F. Lima Filho (2013). Continental oceanic crustal 


\section{Jefferson Tavares Cruz Oliveira et al.}

transition in the Paraíba basin platform, Northeast Brazil, Estudos geológicos, 23, 125-139.

Magalhães, J.R., J.T.C. Oliveira, J.A. Barbosa, D.L. De Castro and P.B. Correia (2014a). Gravimetric framework of continental margin between the Pernambuco and Touros plateaus, Northeast Brazil, in 4th Atlantic Conjugate Margins Conference, Newfoundland, 193-196.

Magalhães, J.R., J.A. Barbosa, J.T.C. Oliveira and M.F. Lima Filho (2014b). Characterization of the ocean-continent transition in the Paraíba Basin and Natal Platform region, NE Brazil, Revista Brasileira de Geofísica, 32, 3, 481-496.

Maia, M.F.B (2012). Revisão Estratigráfica do intervalo Aptiano-Albiano da Bacia de Pernambuco Nordeste do Brasil. M.S. Thesis, Universidade Federal de Pernambuco, Brazil.

Manea, M. and V. Manea (2010). Curie depth vs. flat subduction in Central Mexico, EGU General Assembly, Vienna, $12,7387$.

Manea, M. and V. Manea (2011). Curie Point depth estimates and correlation with subduction in Mexico, Pure Appl. Geophys., 168, 8, 1489-1499.

Manalo, P.C., C.B. Dimalanta, N.T. Ramos, D.V. Faustino-Eslava, K.L. Queaño and G.P. Yumul Jr. (2016). Magnetic signatures and Curie surface trend across an arc-continent collision zone: an example from Central Philippines, Surv. Geophys., 37, 3, 557-578.

Matos, R.M. (1999). History of the northeast Brazilian rift system: kinematic implications for the break up between Brazil and West Africa, in N. R. Cameron, R.H. Bate and V.S. Clure, (Editors), The oil and gas habitats of the South Atlantic, Geol. Soc. Spec. Pub. 153, 55-73.

Maule, C.F., M.E. Purucker, N. Olsen and K. Mosegaard (2005). Heat flux anomalies in Antarctica revealed by sataellite magnetic data, Science, 309, 5733, 464-467.

Medeiros, VC., W. E. Medeiros and E.F. Jardim de Sá (2011). Utilização de imagens aerogamaespectrométricas, Landsat 7 ETM+ e aeromagnéticas no estudo do arcabouço crustal da porção central do domínio da Zona Transversal, Província Borborema, NE do Brasil, Revista Brasileira de Geociências, 29, 1, 83-97.

Mohriak, W. and B. Rosendahl (2003). Transform zones in the South Atlantic rifted continental margins, Geol. Soc. Spec. Publ., 210, 211-228.

Nascimento, M.A.L. (2003). Geologia, geocronologia, geoquímica e petrogênese das rochas ígneas cretácicas da província magmática do Cabo e suas relações com as unidades sedimentares da Bacia de Pernambuco, NE do Brasil. Ph.D. Thesis, Universidade Federal do Rio Grande do Norte, Brazil.

Neves, S.P. and G. Mariano (1999). Assessing the tectonic significance of a large-scale transcurrent shear zone system: Pernambuco Lineamento, Northeastern Brazil, J. Struct. Geol., 21, 1639-1383.

Neves, S.P., P. Monié, O. Bruguier and J.M.R. Silva (2012). Geochronological, thermochronological and thermobarometric constraints on deformation, magmatism and thermal regimes in eastern Borborema Province (NE Brazil), J. S. Am. Earth Sci., 38, 129-146.

Neves, S.P., G. Lages, R.G. Brasilino and A.W.A. Miranda (2015). Paleoproterozoic accretionary and collisional processes and the build-up of the Borborema Province (NE Brazil): Geochronological and geochemical evidence from the Central Domain, J. S. Am. Earth. Sci., 58, 165-187.

Nwankwo, L.I. and A.T. Shehu (2015). Evaluation of Curie-point depths, geothermal gradients and near-surface heat flow from high resolution aeromagnetic (HRAM) data of the entire Sokoto Basin, Nigeria, J. Volcanol. Geoth. Res., 305, 45-55.

Okubo, Y., R.J. Grad, R.O. Hansen, K. Ogawa and H. Tsu (1985). Curie ponit depths of the Island of Kyushu and surrounding areas, Japan, Geophysics, 50, 481-494.

Okubo, Y. and H. Tsu (1992). Depth Estimate of a Two-Dimensional Source Using the Spectrum of One-Dimensional Linear Trending Magnetic Anomaly, in SEG annual meeting, Expanded Abstracts, 522-524.

Okubo, Y. and T. Matsunaga (1994). Curie point depth in northeast Japan and its correlation with regional thermal structure and seismicity, J. Geophys. Res., 99, B11, 22363-22371.

Oliveira, R.G. and W.E. Medeiros (2012). Evidence of buried loads in the base of the crust of Borborema Plateau (NE Brazil) from Bouguer admittance estimates, J. S. Am. Earth Sci., 37, 60-76.

Oliveira, J.T.C. (2013). Análise integrada de dados geofísicos da transição crustal (continente-oceano) da Bacia de Pernambuco, NE do Brasil. M.S. Thesis, Universidade Federal de Pernambuco, Brazil.

O’Reilly, S.Y. and W.L. Griffin (2013). Moho vs crust-mantle boundary: evolution of an idea, Tectonophysics, 609, 535546. 


\section{CPD Unveil NE Brazilian Margin Framework}

Pavlis, N.K., S.A. Holmes, S.C. Kenyon and J.K. Factor (2012). The development and evaluation of the Earth Gravitational Model 2008 (EGM2008), J. Geophys. Res., 117, B04406.

Pérez-Gussinyé, M. (2013). A tectonic model for hyperextension at magma-poor rifted margins: an example from the West Iberia-Newfoundland conjugate margins, Geol. Soc. Spec. Publ., 369, 1, 403-427.

Polônia, J.A.P. (1997). Geometria e cinemática do Rifte do Cabo, litoral Sul do Estado de Pernambuco, M.S. Thesis. Universidade Federal do Rio de Janeiro, Brazil.

Petrunin, A.G., I. Rogozhina, A.P.M. Vaughan, I.T. Kukkonen, M.K. Kaban, I. Koulakov and M. Thomas (2013). Heat flux variations beneath central Greenland's ice due to anomalously thin lithosphere, Nat. Geosci., 6, 746-750.

Quintero, W., O. Campos-Enríquez and O. Hernández (2019). Curie point depth, thermal gradient, and heat flow in the Colombian Caribbean (northwestern South America), Geothermal Energy, 7, 16, 1-20.

Rajaram, M., S.P. Anand, K. Hemant and M. E. Purucker (2009). Curie isotherm of Indian subcontinent from satellite and aeromagnetic data, Earth. Planet. Sci. Lett., 281, 3-4, 145-158.

Ravat, D., A. Pignatelli, I. Nicolosi and M. Chiappini (2007). A study of spectral methods of estimating the depth to the bottom of magnetic sources from near-surface magnetic anomaly data, Geophys. J. Int., 169, 2, 421-434.

Ravat, D., A. Salem, A.M.S. Abdelazis, E. Elawadi, and P. Morgan (2011). Probing magnetic bottom and crustal temperature variations along the Red Sea margin of Egypt, Tectonophysics, 510, 3-4, 337-344.

Reguzzoni, M., D. Sampietro and F. Sansó (2013). Global Moho from the combination of the CRUST2.0 model and GOCE data, Geophys. J. Int., 195, 1, 222-237.

Reston, T.J. (2009). The structure, evolution and symmetry of the magma-poor rifted margins of the North and Central Atlantic: A Synthesis, Tectonophysics, 468, 1-4, 6-27.

Reston, T.J. and G. Manatschal (2011). Rifted margins: building blocks of later collision. in Arc-continent collision,Front. Earth. Sci, Springer, Berlin, 3-21.

Ross, H.E., R.J. Blakely and M. D. Zoback (2006). Testing the use of aeromagnetic data for the determination of Curie depth in California. Geophysics, 71, 5, L51-L59.

Ros, E., M. Pérez-Gussinyé, M. Araújo, M.T. Romeiro, M. Andrés-Martınez, and J.P. Morgan (2017). Lower Crustal Strength Controls on Melting and Serpentinization at Magma-Poor Margins: Potential Implications for the South Atlantic, Geochem. Geophys. Geosys, 18, 12, 4538-4557.

Salem, A., C. Green, D. Ravat, K.H. Singh, P. East, J.D. Fairhead, S. Mogren and E. Biegert (2014). Depth to Curie temperature across the central Red Sea from magnetic data using the de-fractal method, Tectonophysics, 624625, 75-86.

Santos, E.J., W.R. Van Schmus, M. Kozuch and B.B.B. Neves (2010). The Cariris Velhos tectonic event in Northeast Brazil, J. S. Am. Earth. Sci., 29, 1, 61-76.

Sial, A.N., L.E. Long, A.R. Derleide and K. Kawashita K (1981). Potassium-Argon ages and strontium isotope geochemistry of Mesozoic and Tertiary basaltic rocks, Northeastern Brazil, Anais da Academia Brasileira de Ciências, 53, 1, 115-122.

Sial, A.N., L.E. Long and G.S. Borba (1988). Cretaceous Magmatic Province of Cabo, Pernambuco, Northeast Brazil, Revista Brasileira de Geociências, 17, 4, 667-673.

Sibuet, J. and B.E. Tucholke (2013). The geodynamic province of transitional lithosphere adjacent to magma-poor continental margins, Geol. Soc. Spec. Publ., 369, 429-452.

Simpson, R.W, R.C. Jachens, R.J. Blakely and R.W. Saltus (1986). A new Isostatic Residual Gravity Map of the Conterminous United States With a discussion on the significance of isostatic residual anomalies, J. Geophys. Res., 19, B8, 8348-8372.

Souto, Filho J.D. (1984). Estudo do gradiente geotérmico da Bacia Potiguar parte emersa. in 11th Simpósio de Geologia do Nordeste, Abstracts Book, 27-41.

Spector, A. and F.S. Grant (1970). Statistical models for interpreting aeromagnetic data, Geophysics, 35, 2, 293-302.

Sutra, E. and G. Manatschal (2012). How does the continental crust thin in a hyperextended rifted margin? Insights from the Iberia margin, Geology, 40, 2, 139-142.

Tanaka, A., Y. Okubo and O. Matsubayashi (1999). Curie point depth based on spectrum analysis of the magnetic anomaly data in East and Southeast Asia, Tectonophysic. 306, 3-4, 461-470.

Tenzer, Robert., K. Hamayun and P. Vajda (2009). Global maps of the CRUST 2.0 crustal components stripped gravity disturbances, J. Geophys. Res., 114, B05408.

Thébault, E., M. Purucker, K.A. Whaler, B. Langlais and T.J. Sabaka (2010). The magnetic field of Earth's lithosphere, 


\section{Jefferson Tavares Cruz Oliveira et al.}

Space. Sci. Rev., 155, 1, 95-127.

Thybo, H., and I.M. Artemieva (2013). Moho and magmatic underplating in continental lithosphere, Tectonophysics, 609, 605-619.

Turner, J.P., P.F. Green, S.P. Holford and S.R. Lawrence (2008). Thermal History of the Rio Muni (West Africa)-NE Brazil margins during continental breakup, Earth. Planet. Sci. Lett., 270, 3-4, 354-367.

Van Schmus, W.R., E.P. Oliveira, A.F. Silva Filho, S.F. Toteu, J. Penaye and I.P. Guimarães (2008). Proterozoic links between the Borborema Province, NE Brazil, and the Central African Fold Belt, Geol. Soc. Spec. Publ., 294, 6999.

Vauchez, A., S.P. Neves, R. Caby, M. Corsini, M. Egydio-Silva, M. Arthaud and V. Amaro (1995). The Borborema shear zone system, NE Brazil. J. S. Am. Earth. Sci., 8, 3-4, 247-266.

Wasilewski, P.J. and M.A. Mayhew (1992). The Moho as a magnetic boundary revisited, Geophys. Res. Lett., 19, 22, 2259-2262.

Wang, Q., N. Bagdassarov and S. Ji (2013). The Moho as a transition zone: A revisit from seismic and electrical properties of minerals and rocks, Tectonophysics, 609, 395-422.

Wang, J. and C. Li (2015). Crustal magmatism and lithospheric geothermal state of western North America and their implications for a magnetic mantle, Tectonophysics, 638, 112-125. 